Information Sharing and Credit:

Firm-Level Evidence from Transition Countries

Martin Brown, Tullio Jappelli and Marco Pagano

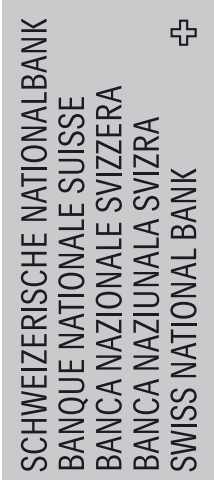

O

(1)

0

ro

a

)

,

(

$\sum$ 
The views expressed in this paper are those of the author(s) and do not necessarily represent those of the Swiss National Bank. Working Papers describe research in progress. Their aim is to elicit comments and to further debate.

ISSN $1660-7716$

๑ 2007 by Swiss National Bank, Börsenstrasse 15, P.0. Box, CH-8022 Zurich 


\title{
Information Sharing and Credit: Firm-Level Evidence from Transition Countries
}

\author{
Martin Brown*, Tullio Jappelli** and Marco Pagano***
}

24 July 2007

\begin{abstract}
We investigate whether information sharing among banks has affected credit market performance in the transition countries of Eastern Europe and the former Soviet Union, using a large sample of firm-level data. Our estimates show that information sharing is associated with improved availability and lower cost of credit to firms. This correlation is stronger for opaque firms than transparent firms, and stronger in countries with weak legal environments than countries with strong legal environments. In cross-sectional estimates, we control for variation in country-level aggregate variables that may affect credit, by examining the differential impact of information sharing across firm types. In panel estimates, we also control for the presence of unobserved heterogeneity at the firm level, as well as for changes in macroeconomic variables and the legal environment.
\end{abstract}

Keywords: information sharing, credit access, transition countries.

JEL classification numbers: D82, G21, G28, O16, P34.

\footnotetext{
* Martin Brown: Swiss National Bank (e-mail: martin.brown@snb.ch).

** Tullio Jappelli: University of Naples Federico II, CSEF and CEPR (e-mail: tullioj@tin.it).

*** Marco Pagano: University of Naples Federico II, CSEF and CEPR (e-mail: mrpagano@tin.it).

Acknowledgements: We benefited from the comments of Mariassunta Giannetti, Luigi Pistaferri, Alessandro Sembenelli, Greg Udell, and seminar participants at the University of Turin, the Swiss National Bank, the Ancona Conference on the Changing Geography of Banking, the $8^{\text {th }}$ Conference of the ECB-CFS Research Network on Financial Integration and Stability in Europe, and the 2007 Skinance conference. We also thank Caralee McLiesh of the World Bank and Utku Teksov of the EBRD for kindly providing us with data, Lukas Burkhard for research assistance and the Unicredit Group for financial support.
} 


\section{Introduction}

When banks evaluate a request for credit, they can either collect information on the applicant first-hand or source this information from other lenders who already dealt with the applicant. Information exchange between lenders, can occur voluntarily via "private credit bureaus" or be enforced by regulation via "public credit registries", and is arguably an important determinant of credit market performance. Theory suggests that information sharing may overcome adverse selection in the credit market (Pagano and Jappelli, 1993) and reduce moral hazard, by motivating borrowers to exert high effort in projects and repay loans (Padilla and Pagano, 2000). Empirical work has identified a positive correlation between measures of information sharing and aggregate credit (Djankov, McLiesh and Shleifer, 2007), as well as a negative correlation between information sharing and default risk (Jappelli and Pagano, 2002).

Information sharing should be particularly relevant for credit market performance in countries with weak company law and creditor rights. Lack of transparency in corporate reporting, due to weak company law, increases information asymmetries in the borrowerlender relationship, reducing incentives for banks to lend. Moreover, weak creditor rights make banks more reluctant to lend to risky firms, as contract enforcement is costly or impossible. The screening and incentive effects of information sharing can mitigate both of these problems.

In this paper we attempt to shed light on the role of information sharing in countries with weak company law and creditor rights. We analyze the impact of private credit bureaus and public credit registries on the availability and cost of credit to firms in 24 transition countries of Eastern Europe and the former Soviet Union. ${ }^{1}$ Pistor, Raiser and Gelfer (2000) document that in these countries the legal environment is particularly unfavourable for lending. Moreover, transition countries are an interesting sample to study because some of them have recently experienced both strong credit market development and considerable institutional

\footnotetext{
${ }^{1}$ We examine data from 24 transition countries, which we classify into three groups according to their status in 2005: European Union (Czech Republic, Estonia, Hungary, Latvia, Lithuania, Poland, Slovak Republic, Slovenia); Commonwealth of Independent States (Armenia, Azerbaijan, Belarus Georgia, Kazakhstan, Kyrgyzstan, Moldova, Russia, Ukraine); Other European Countries (Albania, Bosnia \& Herzegovina, Bulgaria, Croatia, Macedonia, Romania, Serbia \& Montenegro). We exclude the CIS countries Tajikistan, Turkmenistan and Uzbekistan due to lack of data.
} 
change, including the introduction of information sharing systems. Private sector credit has climbed from just $15 \%$ of GDP in 1999 to $25 \%$ at the end of $2004 .^{2}$ The quality of lending has also strongly improved, with the ratio of non-performing loans in banks' portfolios falling from more than $20 \%$ in 1999 to just $10 \%$ at the end of 2004 . Over the same period, seven public registries and seven private credit bureaus have emerged in these countries.

To measure credit market performance, we use firm-level data on credit access and cost of credit, drawn from the EBRD/World Bank "Business Environment and Enterprise Performance Survey" (BEEPS), a representative and large sample of firms. We relate this firm-level credit data to country-level indicators of information sharing, compiled from the "Doing Business" database of the World Bank/IFC (World Bank, 2006).

There are two main benefits from investigating the impact of information sharing using our data set. First, firm-level data allow us to identify the firms that benefit more from information sharing arrangements. For instance, firms that are opaque and costly to screen may gain greater access to credit after the introduction of a credit registry or bureau. We can thus overcome the limitations of aggregate data, which confound the effect of information sharing on individual firms with that arising from compositional changes in the set of firms who obtain credit. The second reason for using the BEEPS data is methodological: it allows us to control for unobserved heterogeneity at the firm level, changes in macroeconomic variables and changes in the legal environment, using panel data constructed from the 2002 and 2005 surveys. As far as we are aware, this is the first study to use firm-level panel data to investigate the relation between information sharing and credit availability. Previous analyses are either based on country-level data (Jappelli and Pagano, 2002; Djankov et al., 2007) or on cross-sectional firm-level data (Galindo and Miller, 2001; Love and Mylenko, 2003).

Both our cross-sectional estimates and our panel estimates show that on average information sharing is associated with more abundant and cheaper credit. Moreover, the cross-sectional correlation between credit availability and information sharing is stronger for opaque firms than transparent ones, where transparency is defined as the reliance on external auditors and the adoption of international accounting standards. Panel estimates also suggest that small firms benefit more from information sharing than larger ones. Taken together, these two results are consistent with the view that information sharing is particularly valuable in

\footnotetext{
${ }^{2}$ The statistics in this paragraph are unweighted country averages, drawn from the EBRD Transition Report (EBRD, 2003; EBRD, 2005).
} 
guiding banks to evaluate credit applicants who would otherwise be too costly to screen. Our results further reveal that the relation between information sharing and credit access (cost) is stronger in countries with weaker legal environments. This finding confirms the conjecture that information sharing is particularly valuable to banks in countries where weak company and bankruptcy law increase the cost of client screening and contract enforcement.

The rest of the paper is organized as follows. Section 2 provides a literature review and presents the hypotheses to be tested. Section 3 describes the data and the specification to be estimated. Sections 4 and 5 present the results obtained with cross-sectional and panel data, respectively. Section 6 summarizes our findings.

\section{Effects of Information Sharing}

In this section we review the models proposed in the literature to capture the effects of information sharing on credit market performance, using them to draw testable predictions for our empirical analysis. We also set our work against the existing empirical evidence in this area, to highlight the value added of our contribution.

\subsection{Theory}

By exchanging information about their customers, banks can improve their knowledge of applicants' characteristics, past behavior and current debt exposure. In principle, this reduction of informational asymmetries can reduce adverse selection problems in lending, as well as change borrowers' incentives to repay, both directly and by changing the competitiveness of the credit market. It can also reduce each bank's uncertainty about the total exposure of the borrower, in the context of multiple-bank lending. The implied effects on lending, interest rates and default rates have been modeled in several ways. ${ }^{3}$

Pagano and Jappelli (1993) show that information sharing reduces adverse selection by improving bank's information on credit applicants. In their model, each bank has private information about local credit applicants, but no information about non-local applicants. If banks exchange information about their client's credit worthiness, they can assess also the

\footnotetext{
${ }^{3}$ See Jappelli and Pagano (2006) for a comprehensive overview of theory and evidence on information sharing.
} 
quality of non-local credit seekers, and lend to them as safely as they do with local clients. The impact of information sharing on aggregate lending in this model is ambiguous. When banks exchange information about borrowers' types, the increase in lending to safe borrowers may fail to compensate for an eventual reduction in lending to risky types.

Information sharing can also create incentives for borrowers to perform in line with banks' interests. Klein (1982) shows that information sharing can motivate borrowers to repay loans, when the legal environment makes it difficult for banks to enforce credit contracts. In this model borrowers repay their loans because they know that defaulters will be blacklisted, reducing external finance in future. Vercammen (1995) and Padilla and Pagano (2000) show that if banks exchange information on defaults, borrowers are motivated to exert more effort in their projects. In both models default is a signal of bad quality for outside banks and carries the penalty of higher interest rates, or no future access to credit. Padilla and Pagano (1997) show that information sharing can also mitigate hold-up problems in lending relationships, by eliciting more competition for borrowers and thereby reducing the informational rents that banks can extract. The reduced hold-up problems can elicit higher effort by borrowers and thereby make banks willing to lower lending rates and extend more credit. ${ }^{4}$

Finally, when a customer can borrow from several banks, each of these may be uncertain about the customer's total exposure, and therefore about his ability to repay. Bennardo, Pagano and Piccolo (2007) show that the danger of overlending that stems from this uncertainty may result in inefficiently scarce credit. Insofar as it makes lending safer, information sharing about seniority or debt exposure can raise investment and welfare.

Given the variety of the informational problems considered in these models, it is not surprising that the predicted effects of information sharing on the volume of lending are not identical across models. For instance, in the adverse selection model of Pagano and Jappelli (1993) the effect on lending is ambiguous, while it is positive in the hold-up model of Padilla and Pagano (1997) and in the multiple-bank lending model of Bennardo et al. (2007). The effect on lending also depends on the type of information being shared: in the model by Padilla and Pagano (2000), sharing only default information increases lending above the level

\footnotetext{
${ }^{4}$ Bouckaert and Degryse (2004) and Gehrig and Stenbacka (2007) show that if banks compete ex ante for clients and customers face switching costs, future informational rents foster banking competition. Since information sharing reduces these rents, in these models it reduces competition, in contrast to Padilla and Pagano (1997).
} 
reached when banks also share their data about borrowers' characteristics. Therefore, whether information sharing is associated with increased lending is left to the empirical evidence.

In contrast, these models offer qualitatively similar predictions about the effect of information sharing on the probability of default and interest rates: they all predict that, in one form or another, communication among banks tends to reduce defaults and thereby equilibrium interest rates. But this prediction is unambiguous only if referred to the probability of default of an individual borrower. When one considers the average default rate, composition effects may overturn the prediction. Suppose that information sharing gives lower-grade borrowers access to credit. Even if each borrower's probability of default is reduced, the aggregate default rate may increase because the relative weight of lower-grade borrowers increases in the total pool. This biases the estimates against the models' prediction that information sharing reduces defaults and interest rates. Thus here is an instance where, in empirical research, borrower-level data may have an edge over aggregate measures. Being free of these composition effects, microeconomic data allow a sharper test of this prediction.

Which firms should benefit more from information sharing between lenders? The stylized models discussed so far offer no predictions about how information sharing affects credit availability and interest rates depending on borrowers' characteristics, such as firm size or accounting standards. But such predictions can be generated by considering how these characteristics affect the banks' incentive to rely on information sharing rather than on direct screening. If direct screening has fixed costs for banks, one may expect that small firms will benefit more from information sharing. Without information sharing, banks would only offer credit to large firms, for whom it pays to screen; with information sharing, banks can also lend to small firms, since they can acquire information on these firms at low cost. A firm's informational transparency - as measured for instance by reliance on international accounting standards or on external auditors - plays a similar role as firm size: direct screening is more cost effective when applied to firms with more transparent accounts, so that without information sharing these firms are more likely to get credit than opaque ones. The introduction of information sharing will enable banks to lend more easily also to opaque firms, by relying on non-accounting information from previous creditors.

This discussion suggests that, in addition to investigating the average effect of information sharing on the availability and cost of credit, our firm-level analysis should also examine its 
differential effect depending on firm size and transparency. We study these differential effects by conducting sample splits based on these firm characteristics.

\subsection{Empirical Evidence}

A growing body of empirical evidence supports the hypothesis that information sharing enhances credit market performance. Analyses of credit bureau data confirm that credit reporting reduces the selection costs of lenders by allowing them to more accurately predict individual loan defaults (Barron and Staten, 2003; Kallberg and Udell, 2003; Powell, Miller, Mylenko, and Majnoni 2004; Luoto, McIntosh, and Wydick, 2007). Experimental evidence by Brown and Zehnder (forthcoming) shows that a public credit registry can motivate borrowers to repay loans, when they would otherwise default.

The impact of information sharing on aggregate credit market performance has been tested by two cross-country studies. Based on their own survey of credit reporting in 43 countries, Jappelli and Pagano (2002) show that bank lending to the private sector is larger and default rates are lower in countries where information sharing is more solidly established and extensive. These cross-sectional relations persist also controlling for other economic and institutional determinants of bank lending, such as country size, GDP, growth rate, and variables capturing respect for the law and protection of creditor rights. Djankov et al. (2007) confirm that private sector credit relative to GDP is positively correlated with information sharing in their recent study of credit market performance and institutional arrangements in 129 countries for the period 1978-2003.

Firm-level data suggests that information sharing may indeed have a differential impact on credit availability for different firm types, in line with the discussion in the previous subsection. Love and Mylenko (2003) combine cross-sectional firm-level data from the 1999 World Bank Business Environment Survey with aggregate data on private and public registries collected in Miller (2003). They find that private credit bureaus are associated with lower perceived financing constraints and a higher share of bank financing, while public 
credit registries are not. They also find that small and young firms benefit particularly from information sharing. ${ }^{5}$

Given that the above studies rely either on aggregate credit information or on crosssectional firm-level data, they cannot clearly disentangle the effect of information sharing from that of firm-level characteristics and of other country-level institutional factors. By relying on panel data, our paper provides the first test that controls both for unobserved firmlevel heterogeneity and for changes in other relevant country-level variables. Controlling for the latter is especially important in the context of the rapid institutional and economic changes experienced by transition economies.

\section{Data}

We draw our data from two main sources. Country level data on information sharing is taken from the World Bank / IFC "Doing Business" database. We relate this to firm-level information on credit availability taken from the EBRD/World Bank Business Environment and Enterprise Performance Survey (BEEPS).

\subsection{Information Sharing}

Between 1991 and 2005 information sharing institutions were established in 17 of the 27 transition countries in Eastern Europe and the former Soviet Union. Table 1 provides an overview of public credit registries (Panel A) and private credit bureaus (Panel B) in 24 transition countries at the end of 2005. The main sources of these data are the "Doing Business" surveys, conducted by the World Bank/IFC (World Bank, 2006). We complement this data with information from our own research ${ }^{6}$. Table 1 shows that public registries (PCRs) and private bureaus (PCBs) are much more frequent in EU transition countries than in

\footnotetext{
${ }^{5}$ Galindo and Miller (2001) also provide evidence that information sharing reduces credit constraints at firm level. Examining balance sheet data of large companies in 23 countries they find a positive relation between credit access and an index of information sharing.

${ }^{6}$ The characteristics of the public credit registry in Kazakhstan were provided to us via questionnaire by the National Bank of Kazakhstan and the Agency of the Republic of Kazakhstan on regulation and supervision of financial markets and organizations.
} 
CIS countries. ${ }^{7}$ Indeed today all of the eight EU transition countries have an active PCR, PCB, or both. In contrast, only three of the nine covered CIS countries have an operating PCR or PCB. The situation is intermediate in other non-EU countries, where in 2004 five out of eight feature a PCR, a PCB or both.

[Table 1 here]

In transition countries it is more common to observe either a PCR or a PCB than both of them. In Table 1, thirteen countries have either a PCR or a PCB, and only four have both. Public registries in transition countries tend to cover larger loans than private bureaus. ${ }^{8}$ Panel A shows that seven of the twelve public credit registries only cover loans which exceed per capita GDP in their country. Further, while all public credit registries cover loans to firms, three do not cover loans to private individuals. In contrast, PCBs tend to focus on credit to private individuals and cover even smallest loans. Panel B shows that all nine private credit bureaus cover loans to private individuals, while four of them do not cover loans to firms.

Based on Table 1, we construct an information sharing index for each country and year between 1996 and 2004. The index measures the presence and structure of public credit registries and private credit bureaus on a scale of 1 to 5 . It is constructed as the maximum of two scores, one for PCRs and one for PCBs. ${ }^{9}$ The PCR score adds one point for fulfilling each of the following five criteria: (i) both firms and individuals are covered, (ii) positive and negative data is collected and distributed, (iii) the registry distributed data which is at least two years old, (iv) the threshold for included loans is below per capita GDP, and (v) the registry has existed for more than 3 years. ${ }^{10}$ The PCB score is computed in a similar way.

7 The CIS countries in our sample are: Armenia, Azerbaijan, Belarus, Georgia, Kazakhstan, Kyrgyzstan, Moldova, Russia, and Ukraine. We exclude Tajikistan, Turkmenistan and Uzbekistan due to lack of data.

${ }^{8}$ This confirms the findings of Miller (2003) for a predominantly Latin American sample.

${ }^{9}$ Computing the information sharing index as the sum of the two scores (instead of the maximum) does not change the qualitative results of the estimation.

${ }^{10}$ Our information sharing index is similar to the "Credit Information Index" reported in the "Doing Business" data of the World Bank / IFC, although differently from that index we do not consider the right of borrowers to access their credit record. 
[Figure 1 here]

Figure 1 plots the average information index from 1996 to 2004, as well as the PCR and PCB scores. The figure highlights that the early years of transition were marked by slow emergence of information sharing institutions, driven by the creation of public registries: prior to 2000 only six PCR were set up, while only two private credit bureaus emerged. ${ }^{11}$ Information sharing activity accelerated after 2001, and also private arrangements started to appear: five public credit registries and seven private credit bureaus were established. This fast development appears set to continue in the coming years, with private credit bureaus currently under construction in at least seven more countries. ${ }^{12}$

\subsection{Credit Access}

We relate our information sharing index to firm-level data on credit access taken from the Business Environment and Enterprise Performance Survey (BEEPS). The EBRD and the World Bank conducted this survey jointly in 1999, 2002 and 2005. Our cross-sectional analysis is based on data from BEEPS 2002, as this survey version contains the most detailed information about firm's access to credit, and relevant characteristics of firms' governance and management ${ }^{13}$. The BEEPS 2002 provides data on 6153 firms in 26 transition countries and covers a representative sample of firms for each of these countries. ${ }^{14}$ We drop all observations from Uzbekistan and Tajikistan, due to lack of institutional indicators for these countries. This leaves us with a sample of 5717 firms from 24 countries for our crosssectional analysis. Our panel analysis is based on responses of 1333 firms who participated in both the 2002 and 2005 surveys. In the following we provide a discussion of the data used in our cross-sectional analysis. Information on the panel sample is provided in section 5 .

\footnotetext{
${ }^{11}$ In 1996 Belarus also introduced a public credit registry. However, the main purpose of this registry is to support bank supervision. We therefore do not list it as a public credit registry in our data.

${ }^{12}$ In, , Armenia, Bulgaria, Croatia, Kazakhstan, Russia, and Serbia projects to establish private credit bureaus have been initiated, but these were not operating by the end of 2005 .

${ }^{13}$ The 2002 survey contains information about a firm's debt-asset ratio as well as the experience of its manager. This information is not available from the more recent 2005 survey version.

${ }^{14}$ The survey covers all countries in which the EBRD is operational, with the exception of Turkmenistan. See Fries, Lysenko, and Polanek (2003) for a detailed description of the BEEPS 2002 survey.
} 
For our cross-sectional analysis we use three indicators of firms' credit access available from the BEEPS 2002 survey. Two indicators capture the extent to which access to loans and cost of credit constrain firm growth, while a third indicator captures firms' actual use of external finance. In two separate questions, firms were asked how problematic the access to financing (as determined by collateral requirements and credit availability) and the costs of financing (interest rates and charges) are for the operation and growth of their business. We code answers to these questions on a scale from 1 to 4 (1=major obstacle, $2=$ moderate obstacle, $3=$ minor obstacles, $4=$ no obstacles) and form our dependent variables Access to Finance and Cost of Finance. ${ }^{15}$ Therefore, higher values of these two variables indicate an improvement in the terms at which credit is available: easier access and lower cost. Besides looking at how financing conditions affect firm performance, we also analyze firms' actual reliance on external finance. To this purpose, we rely on the variable Firm Debt, which measures a firm's total debt as a percentage of its total assets. Table 2 provides summary statistics for the three dependent variables in our cross-sectional analysis by country. Definitions and sources of all dependent variables are provided in the Appendix.

[Table 2 here]

\subsection{Regression Specification}

We start our empirical analysis with cross-sectional regressions using the BEEPS 2002 survey data. The baseline specification relates each of our three dependent variables for firm $i$ in country $j$ to the information sharing index in the firm's country, a vector of other country characteristics, and a vector of firm characteristics that may affect credit access. Our dependent variables were collected during 2002, while information sharing is measured as the average value of the index prior to the survey, i.e. 1996-2000. The fact that we relate firmlevel credit indicators to countrywide measures of information sharing and that information sharing is predetermined with respect to credit variables should address the potential endogeneity of information sharing with respect to credit market performance.

\footnotetext{
${ }^{15}$ Our coding is opposite to that used in the original BEEPS questionnaire, where $4=$ major obstacle, $3=$ moderate obstacle, $2=$ minor obstacles, $1=$ no obstacles. This obviously affects only the sign of our coefficient estimates, not their absolute magnitude or precision.
} 
We include four country-level variables to control for differences in institutions and macroeconomic performance: an index of enterprise reform, a measure of foreign bank presence, per capita GDP, and the inflation rate. Including these variables is particularly important in transition countries, where structural and macroeconomic reforms have coincided with the emergence of information sharing, and may also have affected credit market performance. The variable Enterprise reform index provides a composite index of institutional reforms that make it easier for shareholders and creditors to evaluate and control firms' actions. ${ }^{16}$ Higher values of this index reflect reforms that encourage financial discipline in companies, improve corporate governance and facilitate the enforcement of bankruptcy legislation. Evidence by Pistor et al. (2000) suggests that transition countries with better corporate governance and creditor protection feature higher credit market performance. The variable Foreign bank assets measures the share of assets controlled by foreign owned banks in each country. Recent evidence suggests that foreign bank entry has improved credit market performance in transition countries, reducing intermediation spreads (Bonin, Hasan and Wachtel, 2005) and facilitating credit access (Giannetti and Ongena, forthcoming), although the benefits from foreign bank presence appear to depend strongly on firm size (Brown and Rueda Maurer, 2005). Moreover, foreign bank presence may coincide with information sharing, if these banks are familiar with the benefits of credit reports from their home markets, and therefore tend to patronize private credit bureaus also in their host countries. We include two controls for country specific macroeconomic performance (Per capita GDP, Inflation) as previous evidence suggests that macroeconomic stabilization is conducive to financial intermediation in transition countries (Fries and Taci, 2002). ${ }^{17}$

Table 3 provides summary statistics for our country-level explanatory variables, including the information sharing index. Definitions and sources of all control variables are provided in the Appendix. The table documents strong variation in institutional and macroeconomic indicators. The index of enterprise reform ranges from a minimum value of 1 for Serbia to 3.2 in Hungary. Macroeconomic conditions also range from low inflation (below 2\% in Albania, Armenia, Azerbaijan, Bosnia, and Lithuania) to hyperinflation (above 100\% in Belarus). Confirming our conjecture, most countries with well developed information sharing systems

\footnotetext{
${ }^{16}$ In the estimation, we use the 1996-2000 average of the index of enterprise reform.

${ }^{17}$ For both macroeconomic variables we take the 2000 values to avoid using the extraordinary macroeconomic data from the 1998 and 1999 period in which the Russian crisis took place.
} 
(e.g. Hungary, Czech Republic, and Estonia) also display relatively high levels of institutional reform and macroeconomic stability. This confirms the importance of controlling for these country-level variables, in order to identify the specific role of information sharing.

[Table 3 here]

We include seven firm-level explanatory variables to control for the variation in credit risk and financing requirements across firms. It is customary to regard larger firms as less risky, other things equal. We distinguish small firms from large ones by their number of employees (Small firm $=1-49$, Large firm $\geq 50$ ). It is also customary to regard younger firms as more risky than older firms. However, in transition countries firm age also determines the economic regime under which the firm emerged. Thus, while older firms may be less risky in general, they may be riskier in transition countries, because they emerged during the pre-transition or transition phase. Rather than controlling simply for firm age, we therefore distinguish firms by three categories depending on whether they were established before 1989 (pre-transition), between 1989 and 1993 (transition), after 1993 (post-transition).

We further include two control variables for firm ownership. State-owned firm is a dummy variable that equals one if the government holds a majority stake in the firm. The effect of this variable is ambiguous a priori. On the one hand, state ownership may reduce firm risk in the eye of a bank, due to the possible government bailout in case of default. On the other, state ownership may increase default risk, owing to the political pressures on management to diverge from profit-maximizing policies. Moreover, these firms may receive public funding, which reduces their reliance on credit for investment and therefore relieves their credit constraint to firm growth. The dummy variable Privatised firm equals one for private firms which emerged as the result of a privatisation process, and zero for all de-novo private firms. A successfully privatized firm may be less risky than a de-novo firm, and therefore may have enhanced credit access. Furthermore, they may still have ties to the public sector that make them less dependent on bank finance.

Given the weak legal environment and lack of transparency in corporate governance, borrower-lender relationships in transition countries are likely to suffer from severe adverse selection and moral hazard. As a consequence banks' lending decisions might also be affected by firm characteristics that improve the transparency of their activities. We capture firm 
transparency by a composite indicator of a firm's book-keeping and auditing procedures. The variable Transparency takes the value 0 if a firm does not use international accounting standards or external auditors. The variable takes the value 1 if a firm has either international accounting standards or an external auditor; while it takes the value 2 if both apply. Of course, in general transparency is determined by regulatory standards as well as by firms' choices, and therefore cannot be regarded as an entirely exogenous firm characteristic. For this reason, we shall also control for the potential endogeneity of firm-level transparency using instrumental variables estimation.

[Table 4 here]

In all our regressions we include sector dummies, to control for different finance needs of firms. Table 4 provides summary statistics for our firm-level explanatory variables. Definitions and sources of all control variables are again provided in the Appendix. The table shows that our sample is dominated by small firms (67\%). Exactly half of the firms were established after 1993, and are thus categorized as post-transition firms, while a further $28 \%$ were established in the transition phase of 1989-1993. The majority of firms are privately owned, with only a minor share state-owned (14\%). Of the $86 \%$ privately owned firms in the sample, $83 \%$ are de-novo firms, implying that a total of $14 \%$ of our firms are privatized companies. Our sample displays a low level of transparency on average.

\section{Cross-sectional Estimates}

Tables 5-7 report cross-sectional estimation results for our three dependent variables based on the BEEPS 2002 survey. Table 5 reports full sample and sample split results for the dependent variable Access to finance. In all five regressions reported we regress credit access on our information sharing index, controlling for firm characteristics and country-level indicators of institutional and macroeconomic reform. Although this dependent variable is measured only on an ordinal scale from 1 to 4, we present OLS estimates in Table 5. This makes our results easily comparable with the instrumental variable estimates reported later on. However, ordered probit estimates (not reported for brevity) yield identical qualitative results to those presented in Tables 5 and 6. 
In all specifications, the standard errors of the estimated coefficients are adjusted for cluster effects at the country level. This adjustment is of crucial importance when one estimates the impact of a country-level variable on microeconomic data clustered at the country level: ignoring the within-country correlation can lead to standard errors that are too small, and therefore to conclude that the country-level variable is correlated with the dependent variable, whereas in fact it is not.

[Table 5 here]

In the first column of the table we report our full-sample estimation. The positive coefficient of Information Sharing suggests that, on average, credit access is less of a constraint on firm growth in countries where public credit registries or private credit bureaus are more developed. The relevant coefficient estimate is not only statistically significant but also economically sizeable: for instance, raising the information sharing index from the lowest (0) to the highest observed value (4.6) raises the credit access indicator by 0.5 , which is about $30 \%$ of the sample mean (1.69).

The results in the first regression also show that larger firms, firms that were established in the post-transition phase and more transparent firms perceive credit access as less of a growth constraint. To give an idea of the economic impact of a change in firm-level transparency, consider that a firm with external auditors and international accounting standards has a credit access indicator that is about $10 \%$ higher than the sample mean. As for macroeconomic variables, we find that in countries with lower inflation, credit constraints are lower. The coefficients of our other country-level control variables are imprecisely estimated, probably due to high correlation between these variables.

In the second and third column of Table 5 we re-estimate the model separately for opaque firms (no international accounting standards, no external auditor) and transparent firms (international accounting standards, external auditor, or both), so as to capture the differential impact of information sharing by firm transparency. Comparing the coefficient of Information sharing index in the second and third column of the table, we see that opaque firms benefit more from information sharing than transparent firms. Moreover, the differential impact of 
information sharing by firm transparency is statistically significant. ${ }^{18}$ This finding supports our conjecture that lenders find information sharing more valuable for firms where accounting information is poorer, and therefore adverse selection and incentive problems would otherwise be more severe.

In the fourth and fifth column of Table 5 we conduct a further sample split based on firm size. We do not find evidence that small firms benefit more from information sharing than large firms. The coefficient of information sharing is positive for both small and large firms. While the coefficient for large firms appears to be slightly higher, the difference between the two is not statistically significant. ${ }^{19}$

Table 6 reports estimation results when the Cost of finance indicator is the dependent variable. Again the reported estimations are based on OLS with standard errors adjusted for cluster effects at the country level. Table 6 reports the same full sample and sample split specifications as the previous table. The results generally parallel those of Table 5. The positive coefficient of information sharing in the first column suggests that, on average, the cost of credit is lower in countries where information sharing is more developed, which is consistent with the theoretical prediction discussed in Section 2. Also in line with our previous results, we find that more transparent firms, larger firms and post-transition firms view credit cost as a lower constraint on their operations. A more stable macroeconomic environment again seems to reduce firm-level credit constraints, while the results for other country-level control variables are again imprecise. In contrast to Table 5, we find that the point estimates of the coefficient of the information sharing variable is not only higher for opaque firms but also for smaller firms. However, both results lack statistical significance.

[Table 6 here]

${ }^{18}$ In order to test the statistical significance of this result we run a full-sample OLS regression interacting each variable with Transparency. In this regression, the coefficient of the interaction term Information Sharing $\times$ Transparency yields a negative coefficient of -0.036 , which is statistically different from zero at the 1 percent level.

${ }^{19}$ In order to test the statistical significance of this result we again run a full-sample OLS regression, interacting each variable with firm size. The coefficient of the interaction term Information Sharing $\times$ Small firm is 0.002 and it is not statistically different from zero. 
Table 7 reports estimates obtained for regressions where Firm Debt is the dependent variable. These regressions are estimated with Tobit because the dependent variable is censored at zero. ${ }^{20}$ The positive coefficient of information sharing in the first columns of Table 7 indicates that on average firms are more levered in countries where information sharing is more developed: raising the information sharing index from the lowest to the highest observed value raises the leverage ratio by about 4.2 percentage points, which is almost half the sample mean (9.3\%). Again, firm transparency and size have a positive direct effect on leverage, with large and highly significant coefficients.

In contrast to results for our subjective measures of credit access and cost, the results for Firm Debt reveal a stronger impact of the macroeconomic and institutional environment. We find that firms' reliance on external finance is positively associated with higher per capita income, a stronger presence of foreign banks and weaker enterprise related reforms. The latter result suggests that more stringent corporate governance regulation and effective bankruptcy legislation may have actually reduced the use of external finance in transition countries. This finding contradicts previous empirical results on the benefits of strong company law and creditor rights on financial sector development (see e.g. Djankov et al., 2007). However, in transition countries where many unworthy, but politically connected borrowers may have received credit prior to these reforms, this result may also indicate a positive impact of legal reform on credit market efficiency.

The results of our sample splits in columns 2-5 of Table 7 show that the coefficient of information sharing is higher for opaque than for transparent firms. This confirms our previous finding that information sharing is more beneficial for opaque firms than for transparent firms. In contrast, small firms do not seem to benefit more from information sharing than larger firms.

[Table 7 here]

Our results so far suggest that opaque firms have less access to and higher cost of credit. In line with our predictions though, information sharing between banks reduces the credit

\footnotetext{
${ }^{20}$ The coefficients reported in this table are not adjusted for cluster effects at country level. However, Heckman regressions with standard errors corrected for clustering at the country level yield qualitatively similar results.
} 
constraints of firms and does so particularly for opaque firms. A potential criticism of these results is that firm transparency is not exogenous, as firms can choose their accounting and auditing procedures, and may vary these in order to obtain credit. If firm transparency is endogenous in our data, then both the estimated effect of opaqueness and information sharing may be biased.

In order to control for the endogeneity of firm transparency we estimate instrumental variable regressions of our full sample specification for all three dependent variables. As instruments for firm transparency we apply indicators of managerial experience and corporate governance. More precisely, we use the age of the firm's manager, dummy variables to capture the education of the manager and dummy variables to capture the major shareholder of the firm. The IV estimates reported in Table 8 suggest that the coefficients of Transparency are higher than those reported for Access to Finance in Table 5 and Cost of Finance in Table 6. In contrast, the coefficient of Transparency reported for Firm Debt in Table 7 is higher than in the IV estimates. More importantly, the IV estimates confirm the positive and highly significant impact of Information Sharing on all dependent variables.

[Table 8 here]

\section{Panel Estimates}

The cross-sectional results reported so far may be biased due to omitted country-level and firm-level variables. To tackle these issues, we repeat part of our analysis using a panel generated from the 2002 and 2005 BEEPS. Of the total 9655 firms covered by the BEEPS 2005, 1457 were also surveyed in 2002. Due to our exclusion of Uzbekistan and Tajikistan our panel data set shrinks to 1333 firms. Unfortunately, the BEEPS 2005 does not contain information on firm's external debt, so that our panel estimates are limited to the dependent variables Access to Finance and Cost of Finance. For both variables we effect fixed effects estimates for our two-wave panel, regressing the change in the reported credit constraint per firm (2005-2002) on changes in firm characteristics (size, transparency) and changes in timevarying country-level indicators (information sharing, per capita GDP, foreign bank assets, enterprise reform) over the same period. Obviously the effects of time invariant variables 
(Privatized company, State-owned firm, Transition firm, and Post-transition firm) are not identified in these panel estimates.

[Table 9 here]

Table 9 reports our firm-level fixed-effects estimates for Access to Finance. As in our previous analysis, the first column of the table reports full sample estimates. The significant positive coefficient of information sharing in this column confirms our cross-sectional results: on average an increase in information sharing is associated with improved credit access for firms. It is noteworthy also that the coefficient is similar in size to that of our cross-sectional estimates, even though the sample is much smaller and we control for firm-level effects. Columns two to five of the table report estimates for sample splits by firm transparency and firm size. The results of these sample splits only partly confirm our cross-sectional findings. The positive and significant coefficient of information sharing in columns two and three suggests that that both opaque and transparent firms benefit from information sharing. However, in contrast to our cross-sectional analysis, we do not find a stronger impact of information sharing on credit access of opaque firms. Results reported in columns four and five do however suggest that small firms benefit more from information sharing than larger firms.

Table 10 reports our firm-level fixed-effects estimates for Cost of Finance, again based on OLS regressions. The estimates reported in this table closely resemble those in Table 9: in countries where information sharing has been enhanced firms report that the cost of credit has become less of a constraint for their operations. Again the reported coefficient of information sharing in the full sample estimate is positive, significant, and similar in size to our crosssectional estimate. We further find that the positive impact of information sharing is similar for opaque and transparent firms, while small firms seem to benefit more from information sharing than larger firms.

[Table 10 here]

On the whole, our cross-sectional and panel results suggest that, in transition countries, information sharing is strongly associated with enhanced credit access and lower credit cost. 
One reason for the substantial impact of information sharing in this region may be the weak legal and institutional environment that makes it costly for banks to screen loan applicants and enforce credit contracts. In the final two columns of Table 9 and Table 10 we test this conjecture by exploiting variation in the institutional environment for countries in our sample. We split our sample into low reform countries and high reform countries based on their score on the Enterprise reform index in 2002 and 2005. We categorize those countries "low reform" if their score on this index in both years was below the median value (2.5). According to this classification the following countries are labeled as "low reform": Albania, Armenia, Belarus, Bulgaria, Georgia, Kazakhstan, Kyrgyzstan, Macedonia, Moldova, Romania, Russia, Serbia, Ukraine.

The results in Tables 9 and 10 suggest that within our sample the impact of information sharing on credit access and cost was substantially higher for low reform countries. The coefficient of information sharing on Access to Finance and Cost of Finance is positive and significant for low reform countries (column 6 of each table). In contrast, for high-reform countries (column 7 of each table) the coefficient is not significant in either case. These results support our conjecture that the observed impact of information sharing on credit access and cost is related to the weak institutional environment of many transition countries. The negligible impact of information sharing in "high reform" countries also confirms recent empirical evidence (Djankov et al., 2007) suggesting that information sharing and conducive legal environments are substitutes in fostering credit market development.

\section{Conclusions}

The transition countries of Eastern Europe and the former Soviet Union are a unique environment to test the effects of institutions on credit market performance, since recently they have featured wide variation in institutions both across countries and over time. In this paper we investigate the effects of the variation in one such institution, that is, the information sharing arrangement among banks between 1996 and 2004, using a large sample of firm-level data. The effects of information sharing arrangements are of particular interest in the context of transition countries because they may mitigate the effects of the weak protection afforded to creditors in most of these jurisdictions. 
The use of firm-level data allows us to test theoretical predictions without the biases that composition effects might introduce in tests conducted on aggregate data and to check these predictions by splitting the sample by firm characteristics. Our reliance on firm-level data allows us to achieve also a substantial methodological improvement over previous empirical studies: we control for the presence of unobserved heterogeneity at the firm level, and purge the estimate of the correlation between information sharing and credit market performance from the effects of variation in firm-level characteristics and country-level institutional and macroeconomic variables.

Our cross-sectional and panel estimates show that information sharing is associated with improved availability and lower cost of credit, particularly in transition countries with very weak legal environments. Our cross-sectional estimates suggest that information sharing and firm-level accounting transparency are substitutes in enhancing credit availability: the correlation between information sharing and credit access (or the cost of credit) is stronger for opaque firms than for transparent ones. Our panel estimates further suggest that the impact of information sharing on credit access and cost is stronger for small firms than larger firms. Both these results are consistent with the idea that information sharing is particularly valuable to guide banks in evaluating credit applicants who would be otherwise costly to screen, due to poor accounting information or small loan volumes. Finally, our panel estimates reveal that the relation between information sharing and credit access (cost) is stronger in countries with weaker legal environments. This result confirms the hypothesis that information sharing is particularly valuable to banks in countries where weak company and bankruptcy law increase the cost of client screening and contract enforcement. 


\section{References}

Barron, J. M., and M. Staten (2003), "The Value of Comprehensive Credit Reports: Lessons from the U.S. Experience," in M.J. Miller (ed.), Credit Reporting Systems and the International Economy, Boston: MIT Press.

Bennardo, A., M. Pagano and S. Piccolo (2007), "Information Sharing with Multiple-Bank Lending," mimeo, University of Salerno.

Bonin J. P., I. Hasan, and P. Wachtel (2005): "Bank Performance, Efficiency and Ownership in Transition Countries," Journal of Banking and Finance, 29, 31-53.

Bouckaert, J., and H. Degyrse (2004): "Softening Competition by inducing Switching in Credit Markets," Journal of Industrial Economics, 52, 27-52.

Brown, M., and M. Rueda Maurer (2005), "Bank Ownership, Bank Competition, and Credit Access: Firm-Level Evidence from Transition Countries," mimeo, Swiss National Bank.

Brown, M., and C. Zehnder (forthcoming), "Credit Reporting, Relationship Banking, and Loan Repayment," Journal of Money, Credit, and Banking..

Djankov, S., C. McLiesh and A. Shleifer (2007), "Private Credit in 129 Countries," Journal of Financial Economics, 84, 299-329.

EBRD (2003), “Transition Report 2003: Integration and Regional Cooperation.”

EBRD (2005), "Transition Report 2005: Business in Transition."

EBRD (2006), “Transition Report 2006: Finance in Transition."

Fries S., and A. Taci (2002), "Banking Reform and Development in Transition Countries," EBRD Working Paper 71.

Fries S., T. Lysenko, and S. Polanec (2003), "The 2002 Business Environment and Enterprise Survey: Results from a Survey of 6100 Firms," EBRD Working Paper, 84.

Galindo, A., and M. J. Miller (2001), "Can Credit Registries Reduce Credit Constraints? Empirical Evidence on the Role of Credit Registries in Firm Investment Decisions," Paper prepared for the Annual Meetings of the Inter-American Development Bank, Santiago Chile.

Gehrig, T., and R. Stenbacka (2007), "Information Sharing and Lending Market Competition with Switching Costs and Poaching," European Economic Review, 51, 77-91.

Giannetti M., and S. Ongena (forthcoming), "Financial Integration and Entrepreneurial Activity: Evidence from Foreign Bank Entry in Emerging Markets," Review of Finance.

Jappelli, T., and M. Pagano (2002), "Information Sharing, Lending and Defaults: CrossCountry Evidence," Journal of Banking and Finance 26, 2017-45.

Jappelli T., and M. Pagano (2006), "Role and Effects of Credit Information Sharing," in The Economics of Consumer Credit, edited by G. Bertola, R. Disney and C. Grant. Cambridge: MIT Press, 347-371.

Kallberg, J. G., and G. F. Udell (2003), "The Value of Private Sector Credit Information," Journal of Banking and Finance 27, 449-69. 
Klein, D. B. (1992), "Promise Keeping in the Great Society: A Model of Credit Information Sharing," Economics and Politics 4, 117-36.

Love I., and N. Mylenko (2003), "Credit Reporting and Financing Constraints," World Bank Policy Research Working Paper 3142.

Luoto, J., C. McIntosh, and B. Wydick (2007), "Credit Information Systems in LessDeveloped Countries: Recent History and a Test," Economic Development and Cultural Change, 55, 313-334.

Miller M. J. (2003), "Credit Reporting around the Globe," in M. J. Miller (ed.), Credit Reporting Systems and the International Economy. Cambridge: MIT Press.

Padilla, A. J., and M. Pagano (1997), "Endogenous Communication among Lenders and Entrepreneurial Incentives," Review of Financial Studies 10, 205-236.

Padilla, A. J., and M. Pagano (2000), "Sharing Default Information as a Borrower Discipline Device," European Economic Review 44, 1951-80.

Pagano, M., and T. Jappelli (1993), "Information Sharing in Credit Markets," Journal of Finance 43, 1693-1718.

Pistor K., M. Raiser, and S. Gelfer (2000), "Law and Finance in Transition Countries," Economics of Transition 8, 325-68.

Powell, A., N. Mylenko, M. Miller, and G. Majnoni (2004), "Improving Credit Information, Bank Regulation and Supervision: On the Role and Design of Public Credit Registries," World Bank Policy Research Working Paper 3443.

Vercammen, J. A. (1995), "Credit Bureau Policy and Sustainable Reputation Effects in Credit Markets," Economica 62, 461-78.

World Bank (2006), Doing Business in 2006, Creating Jobs. Oxford: Oxford University Press. 
Appendix. Definition of variables

\section{Firm-level variables (Business Environment and Enterprise Performance Survey - BEEPS)}

Cross sectional analysis (BEEPS 2002): The cross sectional analysis is based on responses by 5717 firms in 24 transition countries to the BEEPS 2002 questionnaire. By design this data set provides a similar sample of non-agricultural firms across all countries. The sample is dominated by small firms (67\%) and private firms (86\%). The sample includes firms from service and manufacturing sectors, with the majority of firms (54\%) have their main activity in the service sector. All firms in the sample are at least 3 years old.

Panel Analysis (BEEPS 2002 \& 2005): The panel analysis is based on responses by 1333 firms interviewed in both the BEEPS 2002 and 2005 surveys. This represents $14 \%$ of the 9655 firms covered by the BEEPS 2005 survey. The sample structure for the 2005 survey resembles by design that of the 2002 survey.

\section{Dependent variables}

Access to finance. Definition: "Can you tell me how problematic is access to finance (e.g. collateral requirement) or financing not available from banks for the operation and growth of your business?" (1=major obstacle, $2=$ moderate obstacle, $3=$ minor obstacle, $4=$ no obstacle). Source: q80a.

Cost of finance. Definition: How problematic is cost of financing (e.g. interest rates and charges) for the operation and growth of your business? (1=major obstacle, $2=$ moderate obstacle, $3=$ minor obstacle, 4=no obstacle). Source: q80b.

Firm Debt. Definition: Ratio of total debt to total assets. Source: q84a1. Only available in the BEEPS 2002.

\section{$\underline{\text { Explanatory variables }}$}

Small Firm. Definition: Dummy Variable if total number of full-time employees less then 50. Source: s4a2.

Transition Firm. Definition: Firm was established in the years 1989-1993. Source: s1a.

Post-transition Firm. Definition: Firm was established after 1993. Source: s1a.

State-owned firm. Definition: State controlled firm (yes/no). Source: s2b.

Privatized firm. Definition: privatized firm (yes/no). Source: q9aa.

Transparency. Based on use of international accounting standards (Source: q73) and of external auditor (q74). Transparency equals 0 if the firm does not use international accounting standards or external auditors, 1 if it uses of the two, 2 if it uses both.

Sector: Definition: Mining, Construction, Manufacturing transport and communication, Wholesale, retail and repairs, Real estate, renting and business service, Hotels and restaurants, Others. Source: q2. 


\section{$\underline{\text { Instrumental Variables }}$}

Age of manager. Definition: Age of manager in the following categories of years: 20-29, 30-39, 4049, 50-59, 60-69, 70-85. Source: q12.

Education of manager. Definition: Dummy variable for highest level of education of the manager in the following categories: no secondary school, secondary schools, vocational training, some university training, completed university degree, completed higher university degree (masters/doctorate). Source: q13.

Firm's shareholders. Definition: Dummy variable for largest shareholder of the firm in the following categories: individual, family, domestic company, foreign company, bank, investment fund, managers of the firm, employees of the firms, government or government agency. Source: q4.

\section{Country-level explanatory variables}

Information sharing index. For each year between 1996 and 2004 we compute an index for private credit bureaus and one for public credit registers: 1 point if it exists for more than 3 years; 1 point if individuals and firms are covered; 1 point if positive and negative data are collected; 1 point if PCR/PCB distributes data which is at least 2 years old; 1 point if threshold loan is below per capita GDP. We then take the maximum of the index for credit bureaus and public credit registers. Our main data source is the Doing Business in 2006 report (World Bank, 2006).

Enterprise Reform Index. Definition: Index of Enterprise Reform (range 1 to $41 / 3$ in steps of 1/3). 1: soft budget constraints and few other reforms to promote corporate governance. 2: 4 1/3: Standards and performance typical of advanced industrial economies: effective corporate control exercised through domestic financial institutions and markets. Per year, 1996-2003. Source: EBRD transition report (EBRD, 2003; EBRD, 2005).

Foreign Bank Assets. Definition: Share of banking sector assets controlled by banks with a majority (at least 50\%) foreign ownership. Per year, 1996-2003. Source: EBRD transition report (EBRD, 2003; EBRD, 2005; EBRD, 2006).

Per capita GDP. Definition: Per capita GDP in '000 US\$. Per year, 1996-2003. Source: IMF International Financial Statistics (IFS): line 99b, line ae, line 99z.

Inflation. Definition: average annual growth rate of CPI. Per year, 1996-2003. Source: IFS (line 64), EBRD transition report (EBRD, 2003; EBRD, 2005). 
Figure 1

\section{Information Sharing in Transition countries over Time}

Values reported in the figure are unweighted averages of the information sharing index and the PCR and PCB scores for the 24 transition countries listed in Table 1. In each country/year, the information sharing index is the maximum of the corresponding PCB and PCR scores.

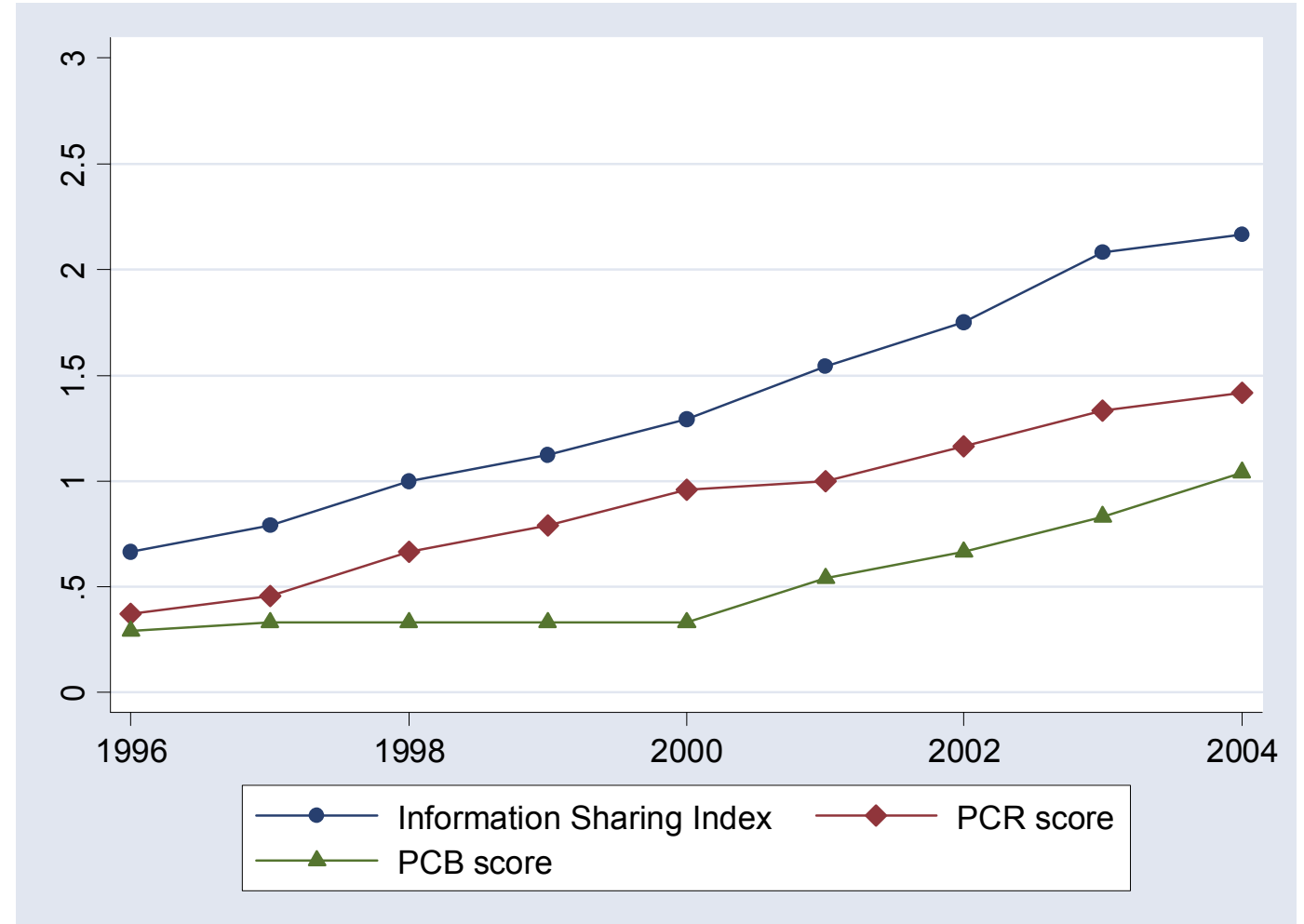




\section{Table 1. Panel A: Public Credit Registries in Transition Countries}

Start of operations: year in which the public credit registry (PCR) started distributing credit records. Individuals: PCR covers private individuals. Firms: PCR covers firms. Negative: PCR collects and distributes negative information. Positive: PCR collects and distributes positive information. Threshold: Minimum Loan size covered by PCR as percentage of GDP per capita. History: Credit reports provide information for more than the most recent 2 years. Source: Doing Business in 2006 (World Bank, 2006); National Bank of Kazakhstan.

\begin{tabular}{|c|c|c|c|c|c|c|c|}
\hline & $\begin{array}{c}\text { Start of } \\
\text { operations }\end{array}$ & $\begin{array}{c}\text { Individuals } \\
\text { covered }\end{array}$ & $\begin{array}{c}\text { Firms } \\
\text { covered }\end{array}$ & $\begin{array}{c}\text { Negative } \\
\text { information }\end{array}$ & $\begin{array}{c}\text { Positive } \\
\text { information }\end{array}$ & Threshold & History \\
\hline \multicolumn{8}{|l|}{ Albania } \\
\hline Armenia & 2003 & $\mathrm{x}$ & $\mathrm{x}$ & $\mathrm{x}$ & $\mathrm{x}$ & 240 & \\
\hline Azerbaijan & 2005 & $\mathrm{x}$ & $\mathrm{x}$ & $\mathrm{x}$ & $\mathrm{x}$ & 107 & $\mathrm{x}$ \\
\hline \multicolumn{8}{|l|}{ Belarus } \\
\hline Bosnia & & & & & & & \\
\hline \multicolumn{8}{|l|}{ Croatia } \\
\hline Czech Rep. & 2002 & & $\mathrm{x}$ & $\mathrm{x}$ & $\mathrm{x}$ & 0 & $\mathrm{x}$ \\
\hline \multicolumn{8}{|l|}{$\begin{array}{l}\text { Estonia } \\
\text { Georgia }\end{array}$} \\
\hline & & & & & & & \\
\hline \multicolumn{8}{|l|}{ Hungary } \\
\hline \multicolumn{7}{|l|}{ Kyrgyz Rep. } & $\mathrm{x}$ \\
\hline Latvia & 2003 & $\mathrm{x}$ & $\mathrm{x}$ & $\mathrm{x}$ & & 0 & $\mathrm{x}$ \\
\hline Lithuania & 1995 & $\mathrm{x}$ & $\mathrm{x}$ & $\mathrm{x}$ & $\mathrm{x}$ & 86 & $\mathrm{x}$ \\
\hline Macedonia & 1998 & $\mathrm{x}$ & $\mathrm{x}$ & $\mathrm{x}$ & $\mathrm{x}$ & 118 & $\mathrm{x}$ \\
\hline \multicolumn{8}{|l|}{ Moldova } \\
\hline \multicolumn{8}{|l|}{ Poland } \\
\hline Romania & 2000 & $\mathrm{x}$ & $\mathrm{x}$ & $\mathrm{x}$ & $\mathrm{x}$ & 187 & $\mathrm{x}$ \\
\hline \multicolumn{8}{|l|}{ Russia } \\
\hline Serbia & 2002 & $\mathrm{x}$ & $\mathrm{x}$ & & $\mathrm{x}$ & 2995 & \\
\hline Slovak Rep. & 1997 & & $\mathrm{x}$ & $\mathrm{x}$ & $\mathrm{x}$ & 0 & \\
\hline Slovenia & 1994 & & $\mathrm{x}$ & $\mathrm{x}$ & $\mathrm{x}$ & 0 & $\mathrm{x}$ \\
\hline Ukraine & & & & & & & \\
\hline
\end{tabular}




\section{Table 1. Panel B: Private Credit Bureaus in Transition Countries}

Start of operations: year in which the private credit bureau (PCB) started distributing credit records. Individuals: PCB covers private individuals. Firms: PCB covers firms. Negative: PCB collects and distributes negative information. Positive: $\mathrm{PCB}$ collects and distributes positive information. Threshold: Minimum Loan size covered by PCB as percentage of GDP per capita. History: Credit reports provide information for more than the most recent 2 years. Source: Doing Business in 2006 (World Bank, 2006).. Two stars indicate that a private credit bureau is under construction.

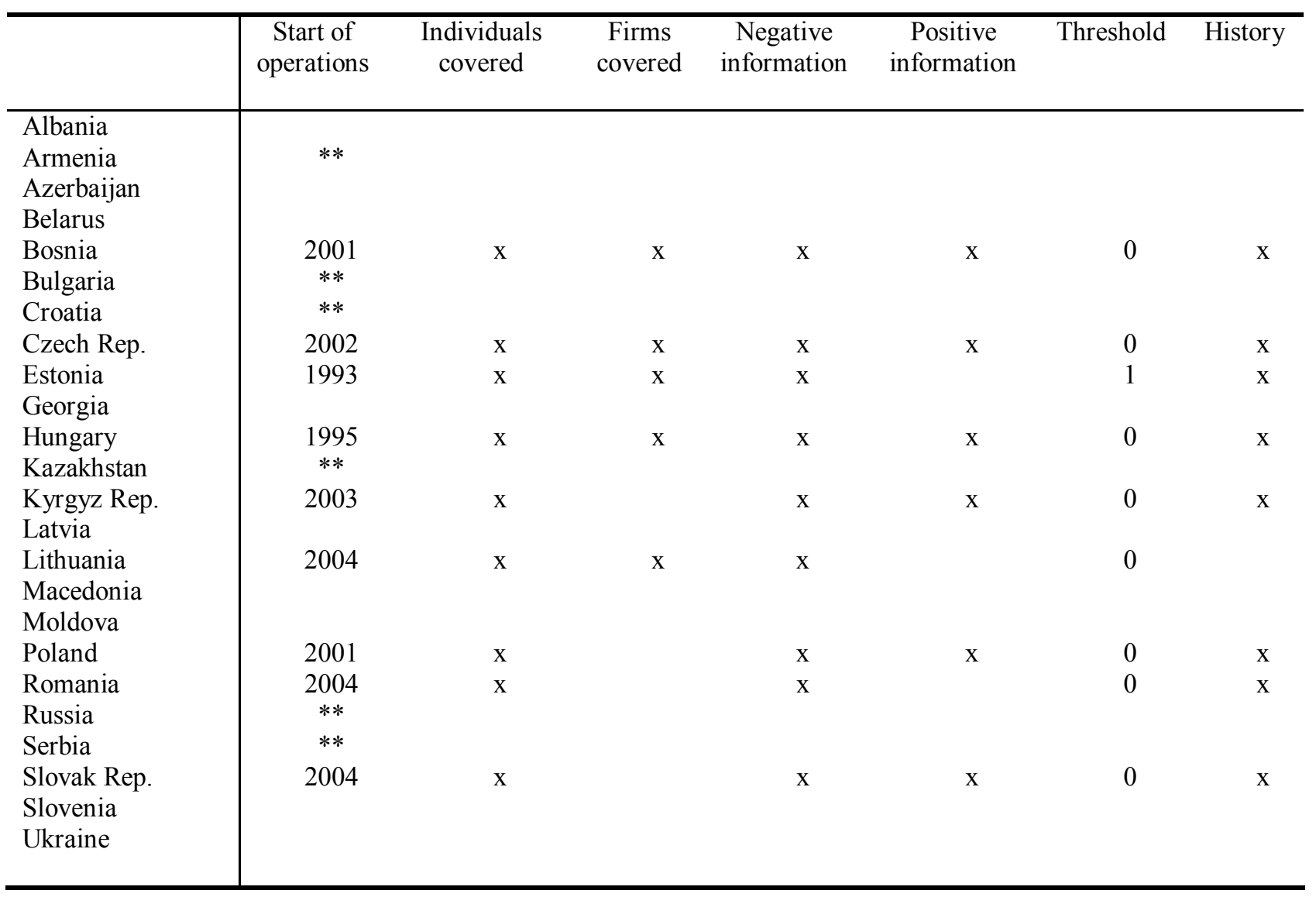




\section{Table 2. Access to Credit, Cost of Credit and Ratio of Debt to Total Assets. Sample Means}

Access to Credit: "How problematic is access to finance for the operation and growth of your business?" (1=major obstacle, $2=$ moderate obstacle, $3=$ minor obstacle, $4=$ no obstacle). Cost of Credit: "How problematic is the cost of finance (e.g. interest rates and charges) for the operation and growth of your business?" ( $1=$ major obstacle, $2=$ moderate obstacle, $3=$ minor obstacle, $4=$ no obstacle). Firm Debt: Debt as percentage of total assets in 2001. Source: BEEPS 2002.

\begin{tabular}{l|cccc}
\hline & Access to finance & Cost of finance & Firm debt & Observations \\
\hline Albania & 1.93 & 1.41 & 19.84 & 170 \\
Armenia & 1.66 & 1.48 & 4.23 & 171 \\
Azerbaijan & 1.84 & 1.80 & 3.45 & 170 \\
Belarus & 1.53 & 1.22 & 7.94 & 250 \\
Bosnia & 1.48 & 1.21 & 12.95 & 250 \\
Bulgaria & 1.20 & 1.12 & 12.87 & 187 \\
Croatia & 1.82 & 1.73 & 14.75 & 268 \\
Czech Rep. & 1.55 & 1.47 & 8.37 & 170 \\
Estonia & 2.06 & 1.99 & 14.77 & 174 \\
Georgia & 1.79 & 1.47 & 6.76 & 250 \\
Hungary & 1.78 & 1.69 & 9.82 & 173 \\
Kazakhstan & 2.00 & 1.84 & 7.64 & 176 \\
Kyrgyz Rep. & 1.76 & 1.60 & 12.26 & 200 \\
Latvia & 2.15 & 1.99 & 10.33 & 170 \\
Lituania & 2.38 & 2.01 & 13.60 & 500 \\
Macedonia & 1.92 & 1.62 & 6.45 & 255 \\
Moldova & 1.51 & 1.05 & 6.84 & 506 \\
Poland & 1.35 & 0.83 & 7.76 & 250 \\
Romania & 1.45 & 1.20 & 10.86 & 170 \\
Russia & 1.69 & 1.76 & 5.03 & 188 \\
Serbia & 1.57 & 1.22 & 10.59 & 463 \\
Slovak Rep. & 1.50 & 1.42 & 15.35 & 5717 \\
Slovenia & 2.18 & 1.80 & 12.95 & \\
Ukraine & 1.56 & 1.38 & 4.53 & \\
& & & & 174 \\
Total & 1.69 & 1.47 & 9.31 & \\
\hline
\end{tabular}


Table 3. Country Level Explanatory Variables

The table reports the country-level explanatory variables used in our cross-sectional analysis. See appendix for detailed description of the variables.

\begin{tabular}{l|ccccc}
\hline Country & $\begin{array}{c}\text { Information } \\
\text { sharing index } \\
(1-5)\end{array}$ & $\begin{array}{c}\text { Enterprise } \\
\text { reform index } \\
(1-4.3)\end{array}$ & $\begin{array}{c}\text { Foreign Bank } \\
\text { Assets } \\
(\%)\end{array}$ & Per capita GDP & Inflation \\
\hline Albania & 0.00 & 2.00 & 27.05 & 1.22 & $(\%)$ \\
Armenia & 0.00 & 2.00 & 44.90 & 0.61 & 0.05 \\
Azerbaijan & 0.00 & 1.76 & 4.40 & 0.63 & 1.77 \\
Belarus & 0.00 & 1.14 & 3.60 & 0.77 & 168.62 \\
Bosnia & 0.00 & 1.70 & 12.70 & 1.24 & 1.90 \\
Bulgaria & 0.80 & 2.24 & 59.05 & 1.59 & 10.32 \\
Croatia & 0.00 & 2.70 & 62.20 & 4.15 & 5.27 \\
Czech Rep & 0.00 & 3.06 & 51.90 & 5.54 & 3.90 \\
Estonia & 4.00 & 3.00 & 93.60 & 4.03 & 4.03 \\
Georgia & 0.00 & 2.00 & 16.75 & 0.65 & 4.06 \\
Hungary & 3.80 & 3.18 & 64.45 & 4.52 & 9.80 \\
Kazakhstan & 3.60 & 2.00 & 19.80 & 1.20 & 18.69 \\
Kyrgyzstan & 0.00 & 2.00 & 20.55 & 0.27 & 13.18 \\
Latvia & 0.00 & 2.76 & 74.20 & 3.22 & 2.65 \\
Lithuania & 4.60 & 2.76 & 45.90 & 3.25 & 1.01 \\
Macedonia & 2.00 & 2.06 & 32.45 & 1.77 & 6.61 \\
Moldova & 0.00 & 2.00 & 37.10 & 0.30 & 31.29 \\
Poland & 0.00 & 3.00 & 60.95 & 4.52 & 10.06 \\
Romania & 0.60 & 2.00 & 45.15 & 1.40 & 45.67 \\
Russia & 0.00 & 1.94 & 10.05 & 1.77 & 20.78 \\
Serbia & 0.00 & 1.00 & 0.45 & 1.03 & 8.82 \\
Slovak Rep & 1.20 & 2.88 & 33.40 & 3.65 & 60.40 \\
Slovenia & 2.80 & 2.70 & 10.10 & 9.51 & 12.04 \\
Ukraine & 0.00 & 2.00 & 10.80 & 0.64 & 28.20 \\
& & & & & \\
Total & 0.85 & 2.25 & 33.93 & 2.42 & 21.04 \\
\hline
\end{tabular}


Table 4. Firm-level Control Variables.

Sample Means

The table reports the country averages of the firm-level control variables used in our cross-sectional analysis. See appendix for detailed description of the variables.

\begin{tabular}{l|cccccc}
\hline Country & Small firm & $\begin{array}{c}\text { Transition } \\
\text { firm }\end{array}$ & $\begin{array}{c}\text { Post- } \\
\text { transition } \\
\text { firm }\end{array}$ & $\begin{array}{c}\text { State-owned } \\
\text { firm }\end{array}$ & $\begin{array}{c}\text { Privatized } \\
\text { company }\end{array}$ & Transparency \\
\hline Albania & 0.71 & 0.17 & 0.75 & 0.08 & 0.11 & 1.41 \\
Armenia & 0.73 & 0.09 & 0.46 & 0.33 & 0.18 & 0.81 \\
Azerbaijan & 0.69 & 0.13 & 0.69 & 0.14 & 0.15 & 0.73 \\
Belarus & 0.69 & 0.30 & 0.52 & 0.05 & 0.18 & 0.68 \\
Bosnia & 0.60 & 0.10 & 0.56 & 0.23 & 0.13 & 1.05 \\
Bulgaria & 0.69 & 0.29 & 0.40 & 0.16 & 0.15 & 0.90 \\
Croatia & 0.67 & 0.36 & 0.37 & 0.13 & 0.15 & 1.03 \\
Czech Rep & 0.66 & 0.51 & 0.38 & 0.10 & 0.13 & 0.57 \\
Estonia & 0.71 & 0.34 & 0.58 & 0.09 & 0.14 & 1.71 \\
Georgia & 0.75 & 0.09 & 0.66 & 0.20 & 0.16 & 1.32 \\
Hungary & 0.67 & 0.42 & 0.33 & 0.18 & 0.05 & 0.90 \\
Kazakhstan & 0.70 & 0.24 & 0.62 & 0.18 & 0.15 & 0.86 \\
Kyrgyzstan & 0.62 & 0.17 & 0.58 & 0.24 & 0.16 & 0.78 \\
Latvia & 0.70 & 0.27 & 0.59 & 0.11 & 0.17 & 1.20 \\
Lithuania & 0.67 & 0.29 & 0.54 & 0.17 & 0.16 & 0.97 \\
Macedonia & 0.70 & 0.28 & 0.48 & 0.14 & 0.04 & 0.49 \\
Moldova & 0.68 & 0.16 & 0.68 & 0.20 & 0.16 & 1.26 \\
Poland & 0.66 & 0.32 & 0.33 & 0.09 & 0.14 & 0.72 \\
Romania & 0.60 & 0.40 & 0.46 & 0.13 & 0.15 & 0.66 \\
Russia & 0.67 & 0.23 & 0.59 & 0.15 & 0.13 & 0.53 \\
Serbia & 0.61 & 0.31 & 0.35 & 0.10 & 0.17 & 0.59 \\
Slovak Rep & 0.64 & 0.42 & 0.41 & 0.12 & 0.15 & 0.67 \\
Slovenia & 0.77 & 0.43 & 0.29 & 0.20 & 0.09 & 0.80 \\
Ukraine & 0.67 & 0.23 & 0.57 & 0.11 & 0.14 & 1.03 \\
& & & & & & \\
Total & 0.67 & 0.28 & 0.50 & 0.14 & 0.14 & 0.86 \\
\hline
\end{tabular}




\section{Table 5. Access to Finance}

The table reports OLS estimates for "How problematic is access to finance for the operation and growth of your business?" ( $1=$ major obstacle, $2=$ moderate obstacle, $3=$ minor obstacle, $4=$ no obstacle). Each regression includes sector dummies. Opaque firms are those that don't have external auditors or international accounting standards. Transparent firms are those with external auditors or international accounting standards. Small and large firms are, respectively, firms with less or more than 50 employees. Robust t-statistics are reported in parentheses. Standard errors are adjusted for cluster effects at the country level. One star indicates that the estimated coefficient is significantly different from zero at $10 \%$ level; two stars at $5 \%$; three stars at $1 \%$.

\begin{tabular}{|c|c|c|c|c|c|}
\hline & Baseline & Opaque & Transparent & Small & Large \\
\hline Information sharing & $\begin{array}{c}0.110 \\
(4.03)^{* * *}\end{array}$ & $\begin{array}{c}0.158 \\
(7.14)^{* * *}\end{array}$ & $\begin{array}{c}0.089 \\
(2.62)^{* *}\end{array}$ & $\begin{array}{c}0.109 \\
(3.60)^{* * *}\end{array}$ & $\begin{array}{c}0.117 \\
(4.59)^{* * *}\end{array}$ \\
\hline Transition firm & $\begin{array}{l}0.112 \\
(1.66)\end{array}$ & $\begin{array}{l}0.102 \\
(1.07)\end{array}$ & $\begin{array}{l}0.116 \\
(1.49)\end{array}$ & $\begin{array}{c}0.119 \\
(1.91)^{*}\end{array}$ & $\begin{array}{l}0.072 \\
(0.72)\end{array}$ \\
\hline Post-transition firm & $\begin{array}{c}0.215 \\
(3.87)^{* * *}\end{array}$ & $\begin{array}{l}0.154 \\
(1.65)\end{array}$ & $\begin{array}{c}0.243 \\
(3.36)^{* * *}\end{array}$ & $\begin{array}{c}0.211 \\
(4.06)^{* * *}\end{array}$ & $\begin{array}{c}0.216 \\
(2.43)^{* *}\end{array}$ \\
\hline Small firm & $\begin{array}{c}-0.155 \\
(4.90)^{* * *}\end{array}$ & $\begin{array}{c}-0.222 \\
(2.96)^{* * *}\end{array}$ & $\begin{array}{c}-0.150 \\
(3.22)^{* * *}\end{array}$ & & \\
\hline Privatized company & $\begin{array}{l}0.096 \\
(1.42)\end{array}$ & $\begin{array}{l}-0.029 \\
(0.26)\end{array}$ & $\begin{array}{c}0.149 \\
(1.89)^{*}\end{array}$ & $\begin{array}{c}0.180 \\
(2.08)^{* *}\end{array}$ & $\begin{array}{l}0.024 \\
(0.28)\end{array}$ \\
\hline State-owned firm & $\begin{array}{c}0.135 \\
(1.93)^{*}\end{array}$ & $\begin{array}{l}0.135 \\
(1.10)\end{array}$ & $\begin{array}{c}0.145 \\
(1.81)^{*}\end{array}$ & $\begin{array}{l}0.132 \\
(1.37)\end{array}$ & $\begin{array}{l}0.073 \\
(0.82)\end{array}$ \\
\hline Transparency & $\begin{array}{c}0.146 \\
(5.44)^{* * *}\end{array}$ & & & $\begin{array}{c}0.152 \\
(4.71)^{* * *}\end{array}$ & $\begin{array}{c}0.124 \\
(3.42)^{* * *}\end{array}$ \\
\hline Per capita GDP & $\begin{array}{c}0.034 \\
(1.84)^{*}\end{array}$ & $\begin{array}{l}-0.008 \\
(0.31)\end{array}$ & $\begin{array}{c}0.054 \\
(2.53)^{* *}\end{array}$ & $\begin{array}{l}0.027 \\
(1.17)\end{array}$ & $\begin{array}{c}0.049 \\
(2.82)^{* * *}\end{array}$ \\
\hline Inflation & $\begin{array}{l}-0.170 \\
(1.87)^{*}\end{array}$ & $\begin{array}{c}-0.207 \\
(2.87) * * *\end{array}$ & $\begin{array}{l}-0.169 \\
(1.36)\end{array}$ & $\begin{array}{c}-0.221 \\
(2.25)^{* *}\end{array}$ & $\begin{array}{l}-0.076 \\
(0.79)\end{array}$ \\
\hline Foreign bank assets & $\begin{array}{l}-0.003 \\
(1.03)\end{array}$ & $\begin{array}{c}-0.008 \\
(2.12)^{* *}\end{array}$ & $\begin{array}{l}-0.000 \\
(0.02)\end{array}$ & $\begin{array}{l}-0.005 \\
(1.24)\end{array}$ & $\begin{array}{l}-0.000 \\
(0.01)\end{array}$ \\
\hline Enterprise reform index & $\begin{array}{l}-0.071 \\
(0.51)\end{array}$ & $\begin{array}{l}0.174 \\
(1.05)\end{array}$ & $\begin{array}{l}-0.215 \\
(1.32)\end{array}$ & $\begin{array}{l}-0.022 \\
(0.12)\end{array}$ & $\begin{array}{l}-0.168 \\
(1.79)^{*}\end{array}$ \\
\hline Constant & $\begin{array}{c}1.519 \\
(6.73)^{* * *}\end{array}$ & $\begin{array}{c}1.405 \\
(7.30)^{* * *}\end{array}$ & $\begin{array}{c}1.816 \\
(6.03)^{* * *}\end{array}$ & $\begin{array}{c}1.272 \\
(4.51)^{* * *}\end{array}$ & $\begin{array}{c}1.796 \\
(7.56)^{* * *}\end{array}$ \\
\hline Observations & 5392 & 2075 & 3317 & 3631 & 1761 \\
\hline R-squared & 0.05 & 0.05 & 0.04 & 0.05 & 0.05 \\
\hline
\end{tabular}




\section{Table 6. Cost of Finance}

The table reports OLS estimates for: "How problematic is cost of financing (e.g. interest rates and charges) for the operation and growth of your business?" (1=major obstacle, $2=$ moderate obstacle, $3=$ minor obstacle, $4=$ no obstacle). Each regression includes sector dummies. Opaque firms are those that don't have external auditors or international accounting standards. Transparent firms are those with external auditors or international accounting standards. Small and large firms are, respectively, firms with less or more than 50 employees. Robust t-statistics are reported in parentheses. Standard errors are adjusted for cluster effects at the country level. One star indicates that the estimated coefficient is significantly different from zero at $10 \%$ level; two stars at $5 \%$; three stars at $1 \%$.

\begin{tabular}{|c|c|c|c|c|c|}
\hline & Baseline & Opaque & Transparent & Small & Large \\
\hline Information sharing & $\begin{array}{c}0.126 \\
(2.95)^{* * *}\end{array}$ & $\begin{array}{c}0.139 \\
(3.62) * * *\end{array}$ & $\begin{array}{c}0.110 \\
(2.38)^{* *}\end{array}$ & $\begin{array}{c}0.132 \\
(3.03) * * *\end{array}$ & $\begin{array}{c}0.110 \\
(246) * *\end{array}$ \\
\hline Transition firm & $\begin{array}{l}0.086 \\
(1.23)\end{array}$ & $\begin{array}{l}0.049 \\
(0.35)\end{array}$ & $\begin{array}{l}0.083 \\
(1.13)\end{array}$ & $\begin{array}{l}0.090 \\
(1.28)\end{array}$ & $\begin{array}{l}0.045 \\
(0.49)\end{array}$ \\
\hline Post-transition firm & $\begin{array}{c}0.157 \\
(2.35)^{* *}\end{array}$ & $\begin{array}{l}0.053 \\
(0.46)\end{array}$ & $\begin{array}{c}0.196 \\
(2.23)^{* *}\end{array}$ & $\begin{array}{c}0.163 \\
(2.57)^{* *}\end{array}$ & $\begin{array}{l}0.137 \\
(1.23)\end{array}$ \\
\hline Small firm & $\begin{array}{l}-0.081 \\
(1.74)^{*}\end{array}$ & $\begin{array}{c}-0.216 \\
(2.81)^{* * *}\end{array}$ & $\begin{array}{l}-0.040 \\
(0.62)\end{array}$ & & \\
\hline Privatized company & $\begin{array}{l}0.066 \\
(1.10)\end{array}$ & $\begin{array}{l}0.035 \\
(0.39)\end{array}$ & $\begin{array}{l}0.084 \\
(1.00)\end{array}$ & $\begin{array}{c}0.167 \\
(2.05)^{*}\end{array}$ & $\begin{array}{l}-0.030 \\
(0.33)\end{array}$ \\
\hline State-owned firm & $\begin{array}{c}0.205 \\
(2.91)^{* * *}\end{array}$ & $\begin{array}{l}0.202 \\
(1.39)\end{array}$ & $\begin{array}{c}0.195 \\
(2.55)^{* *}\end{array}$ & $\begin{array}{c}0.221 \\
(2.65)^{* *}\end{array}$ & $\begin{array}{l}0.164 \\
(1.60)\end{array}$ \\
\hline Transparency & $\begin{array}{c}0.065 \\
(2.43)^{* *}\end{array}$ & & & $\begin{array}{c}0.091 \\
(2.48)^{* *}\end{array}$ & $\begin{array}{l}-0.015 \\
(0.41)\end{array}$ \\
\hline Per capita GDP & $\begin{array}{l}-0.002 \\
(0.10)\end{array}$ & $\begin{array}{l}-0.061 \\
(2.00)^{*}\end{array}$ & $\begin{array}{l}0.026 \\
(1.04)\end{array}$ & $\begin{array}{l}-0.005 \\
(0.18)\end{array}$ & $\begin{array}{l}0.004 \\
(0.19)\end{array}$ \\
\hline Inflation & $\begin{array}{l}-0.205 \\
(2.04)^{*}\end{array}$ & $\begin{array}{c}-0.217 \\
(3.00)^{* * *}\end{array}$ & $\begin{array}{l}-0.195 \\
(1.45)\end{array}$ & $\begin{array}{l}-0.195 \\
(1.73)^{*}\end{array}$ & $\begin{array}{c}-0.234 \\
(2.35)^{* *}\end{array}$ \\
\hline Foreign bank assets & $\begin{array}{l}-0.004 \\
(1.13)\end{array}$ & $\begin{array}{c}-0.012 \\
(2.59)^{* *}\end{array}$ & $\begin{array}{l}-0.001 \\
(0.23)\end{array}$ & $\begin{array}{l}-0.005 \\
(1.22)\end{array}$ & $\begin{array}{l}-0.002 \\
(0.55)\end{array}$ \\
\hline Enterprise reform index & $\begin{array}{l}0.045 \\
(0.24)\end{array}$ & $\begin{array}{c}0.368 \\
(1.95)^{*}\end{array}$ & $\begin{array}{l}-0.092 \\
(0.42)\end{array}$ & $\begin{array}{l}0.038 \\
(0.17)\end{array}$ & $\begin{array}{l}0.055 \\
(0.38)\end{array}$ \\
\hline Constant & $\begin{array}{c}1.283 \\
(4.16)^{* * *}\end{array}$ & $\begin{array}{c}1.149 \\
(5.88)^{* * *}\end{array}$ & $\begin{array}{c}1.436 \\
(3.37)^{* * *}\end{array}$ & $\begin{array}{c}1.209 \\
(3.26)^{* * *}\end{array}$ & $\begin{array}{c}1.323 \\
(4.80)^{* * *}\end{array}$ \\
\hline Observations & 5450 & 2093 & 3357 & 3661 & 1789 \\
\hline R-squared & 0.05 & 0.07 & 0.04 & 0.05 & 0.05 \\
\hline
\end{tabular}




\section{Table 7. Firm Debt}

The table reports Tobit regression estimates for the ratio of total debt to total assets (expressed in percentage values). Each regression includes sector dummies. Opaque firms are those that don't have external auditors or international accounting standards. Transparent firms are those with external auditors or international accounting standards. Small and large firms are, respectively, firms with less or more than 50 employees. T-statistics are reported in parentheses. One star indicates that the estimated coefficient is significantly different from zero at $10 \%$ level; two stars at $5 \%$; three stars at $1 \%$.

\begin{tabular}{|c|c|c|c|c|c|}
\hline & Baseline & Opaque & Transparent & Small & Large \\
\hline Information sharing & $\begin{array}{c}0.913 \\
(2.22)^{* *}\end{array}$ & $\begin{array}{c}2.411 \\
(3.12)^{* * *}\end{array}$ & $\begin{array}{l}0.318 \\
(0.65)\end{array}$ & $\begin{array}{l}0.661 \\
(1.25)\end{array}$ & $\begin{array}{c}1.282 \\
(1.93)^{*}\end{array}$ \\
\hline Transition firm & $\begin{array}{l}2.637 \\
(1.50)\end{array}$ & $\begin{array}{l}1.297 \\
(0.39)\end{array}$ & $\begin{array}{l}3.177 \\
(1.54)\end{array}$ & $\begin{array}{l}2.840 \\
(1.08)\end{array}$ & $\begin{array}{l}3.607 \\
(1.49)\end{array}$ \\
\hline Post-transition firm & $\begin{array}{l}1.741 \\
(1.01)\end{array}$ & $\begin{array}{l}0.576 \\
(0.17)\end{array}$ & $\begin{array}{l}2.579 \\
(1.28)\end{array}$ & $\begin{array}{l}2.028 \\
(0.81)\end{array}$ & $\begin{array}{l}1.066 \\
(0.43)\end{array}$ \\
\hline Small firm & $\begin{array}{c}-9.127 \\
(6.65)^{* * *}\end{array}$ & $\begin{array}{r}-1.898 \\
(0.66)\end{array}$ & $\begin{array}{c}-11.050 \\
(7.08)^{* * *}\end{array}$ & & \\
\hline Privatized company & $\begin{array}{c}2.977 \\
(1.65)^{*}\end{array}$ & $\begin{array}{l}4.839 \\
(1.28)\end{array}$ & $\begin{array}{l}2.071 \\
(1.01)\end{array}$ & $\begin{array}{r}-4.066 \\
(1.47)\end{array}$ & $\begin{array}{c}8.088 \\
(3.33)^{* * *}\end{array}$ \\
\hline State-owned firm & $\begin{array}{c}4.513 \\
(2.33)^{* *}\end{array}$ & $\begin{array}{c}8.701 \\
(2.21)^{* *}\end{array}$ & $\begin{array}{l}3.281 \\
(1.48)\end{array}$ & $\begin{array}{l}2.555 \\
(0.84)\end{array}$ & $\begin{array}{c}8.529 \\
(3.28)^{* * * *}\end{array}$ \\
\hline Transparency & $\begin{array}{c}3.774 \\
(4.97)^{* * *}\end{array}$ & & & $\begin{array}{c}3.887 \\
(4.01)^{* * *}\end{array}$ & $\begin{array}{c}3.798 \\
(3.03)^{* * *}\end{array}$ \\
\hline Per capita GDP & $\begin{array}{c}2.760 \\
(6.14)^{* * *}\end{array}$ & $\begin{array}{c}2.885 \\
(3.71)^{* * *}\end{array}$ & $\begin{array}{c}2.603 \\
(4.67)^{* * *}\end{array}$ & $\begin{array}{c}3.227 \\
(5.70)^{* * *}\end{array}$ & $\begin{array}{c}1.964 \\
(2.62)^{* * *}\end{array}$ \\
\hline Inflation & $\begin{array}{l}-1.340 \\
(0.74)\end{array}$ & $\begin{array}{l}2.912 \\
(1.00)\end{array}$ & $\begin{array}{c}-4.935 \\
(2.10)^{* *}\end{array}$ & $\begin{array}{l}-3.209 \\
(1.37)\end{array}$ & $\begin{array}{l}1.469 \\
(0.51)\end{array}$ \\
\hline Foreign bank assets & $\begin{array}{c}0.289 \\
(7.39)^{* * *}\end{array}$ & $\begin{array}{c}0.249 \\
(3.28)^{* * *}\end{array}$ & $\begin{array}{c}0.305 \\
(6.61)^{* * *}\end{array}$ & $\begin{array}{c}0.331 \\
(6.62)^{* * *}\end{array}$ & $\begin{array}{c}0.215 \\
(3.41)^{* * *}\end{array}$ \\
\hline Enterprise reform index & $\begin{array}{c}-13.991 \\
(6.00)^{* * *}\end{array}$ & $\begin{array}{c}-14.925 \\
(3.80)^{* * *}\end{array}$ & $\begin{array}{c}-13.624 \\
(4.55)^{* * *}\end{array}$ & $\begin{array}{c}-19.131 \\
(6.33)^{* * *}\end{array}$ & $\begin{array}{l}-5.712 \\
(1.56)\end{array}$ \\
\hline Constant & $\begin{array}{l}-5.399 \\
(1.15)\end{array}$ & $\begin{array}{c}-10.903 \\
(1.42)\end{array}$ & $\begin{array}{l}0.934 \\
(0.16)\end{array}$ & $\begin{array}{l}-2.538 \\
(0.43)\end{array}$ & $\begin{array}{c}-27.698 \\
(3.74)^{* * *}\end{array}$ \\
\hline Observations & 5717 & 2211 & 3506 & 3856 & 1861 \\
\hline
\end{tabular}




\section{Table 8. Instrumental Variable Estimates}

The table reports Instrumental Variables estimates for three dependent variables: Access to Finance (OLS estimates), Cost of Finance (OLS estimates), and Firm Debt (Tobit estimates). The instruments for transparency are: age of manager, five dummies for the education of the manager, and ten dummies for the type of the firm's largest shareholder. Each regression includes sector dummies. Robust t-statistics are reported in parentheses. Standard errors are adjusted for cluster effects at the country level. One star indicates that the estimated coefficient is significantly different from zero at $10 \%$ level; two stars at $5 \%$; three stars at $1 \%$.

\begin{tabular}{l|ccc}
\hline & Access to finance & Cost of finance & Firm debt \\
\hline Information sharing & & & \\
& 0.091 & 0.115 & 1.081 \\
Transition firm & $(3.05)^{* * *}$ & $(2.88)^{* * *}$ & $(2.52)^{* *}$ \\
& 0.099 & 0.081 & 2.979 \\
Post-transition firm & $(1.31)$ & $(1.11)$ & $(1.69)^{*}$ \\
& 0.202 & 0.150 & 2.046 \\
Small firm & $(3.41)^{* * *}$ & $(2.33)^{* *}$ & $(1.18)$ \\
& 0.003 & 0.014 & -10.640 \\
Privatized company & $(0.08)$ & $(0.39)$ & $(5.83)^{* * *}$ \\
& 0.022 & 0.026 & 3.914 \\
State-owned firm & $(0.30)$ & $(0.41)$ & $(2.06)^{* *}$ \\
& 0.089 & 0.182 & 4.922 \\
Transparency & $(1.33)$ & $(2.76)^{* *}$ & $(2.50)^{* *}$ \\
& 0.537 & 0.295 & 0.225 \\
Per capita GDP & $(5.03)^{* * *}$ & $(3.52)^{* * *}$ & $(0.07)$ \\
Inflation & 0.052 & 0.008 & 2.620 \\
& $(2.18)^{* *}$ & $(0.27)$ & $(5.59)^{* * *}$ \\
Foreign bank assets & -0.130 & -0.178 & -1.637 \\
& $(1.57)$ & $(1.90)^{*}$ & $(0.89)$ \\
Enterprise reform index & -0.005 & -0.005 & 0.301 \\
& $(1.52)$ & $(1.42)$ & $(7.30)^{* * *}$ \\
Constant & -0.062 & 0.056 & -14.012 \\
& $(0.45)$ & $(0.32)$ & $(6.02)^{* * *}$ \\
Observations & 1.131 & 1.033 & -1.813 \\
& $(4.37)^{* * *}$ & $(3.43)^{* * *}$ & $(0.33)$ \\
& & & 5678 \\
\hline
\end{tabular}




\section{Table 9. Fixed Effects Panel Estimates: Access to Finance}

The table reports OLS estimates with firm-level fixed effects using the panel component of the 2002 and 2005 BEEPS. The dependent variable is: "How problematic is access to finance for the operation and growth of your business?" (1=major obstacle, $2=$ moderate obstacle, $3=$ minor obstacle, 4=no obstacle). Opaque firms are those that did not have external auditors or international accounting standards in both 2002 and 2005. Transparent firms are those with external auditors or international accounting standards in both 2002 and 2005. Small and large firms are, respectively, firms with less or more than 50 employees in both 2002 and 2005. The groups of High and Low reform countries are defined on the basis of the Enterprise reform index. High reform countries are those where the value of this index is higher then the median value (2.5) in both 2002 and 2005: Croatia, Czech Rep, Estonia, Hungary, Latvia, Lithuania, Poland, Slovak Rep, Slovenia. Low reform countries are those where the value of this index is lower then the median value (2.5) in both 2002 and 2005: Albania, Armenia, Belarus, Bulgaria, Georgia, Kazakhstan, Kyrgyzstan, Macedonia, Moldova, Romania, Russia, Serbia, Ukraine. T-statistics are reported in parentheses. One star indicates that the estimated coefficient is significantly different from zero at $10 \%$ level; two stars at $5 \%$; three stars at $1 \%$.

\begin{tabular}{l|c|ccc|cc|cc}
\hline & Baseline & Opaque & $\begin{array}{c}\text { Transpa- } \\
\text { rent }\end{array}$ & $\begin{array}{c}\text { Small } \\
\text { firm }\end{array}$ & $\begin{array}{c}\text { Large } \\
\text { firm }\end{array}$ & $\begin{array}{c}\text { Low } \\
\text { reform }\end{array}$ & $\begin{array}{c}\text { High } \\
\text { reform }\end{array}$ \\
\hline Information sharing index & 0.160 & 0.207 & 0.229 & 0.172 & 0.057 & 0.227 & -0.119 \\
& $(3.49)^{* * *}$ & $(2.19)^{* *}$ & $(3.28)^{* * *}$ & $(2.90)^{* * *}$ & $(0.66)$ & $(3.16)^{* * *}$ & $(1.36)$ \\
Small firm & 0.208 & 0.135 & 0.197 & & & 0.230 & 0.072 \\
& $(1.47)$ & $(0.31)$ & $(1.13)$ & & & $(1.29)$ & $(0.28)$ \\
Transparency & 0.060 & & & 0.017 & 0.194 & 0.034 & 0.147 \\
& $(1.13)$ & & & $(0.26)$ & $(1.89)^{*}$ & $(0.48)$ & $(1.56)$ \\
Per capita GDP & 0.017 & 0.011 & 0.062 & 0.031 & -0.027 & 0.052 & -0.103 \\
Inflation & $(0.62)$ & $(0.19)$ & $(1.60)$ & $(0.91)$ & $(0.51)$ & $(0.31)$ & $(2.08)^{* *}$ \\
& -0.002 & -0.003 & -0.004 & -0.004 & -0.000 & -0.001 & -0.023 \\
Foreign bank assets & $(1.12)$ & $(0.93)$ & $(1.53)$ & $(1.97)^{* *}$ & $(0.10)$ & $(0.53)$ & $(3.24)^{* * *}$ \\
& -0.001 & 0.010 & -0.005 & -0.004 & 0.004 & -0.007 & -0.006 \\
Enterprise reform index & $(0.35)$ & $(1.38)$ & $(1.24)$ & $(1.11)$ & $(0.71)$ & $(0.94)$ & $(1.48)$ \\
& -0.022 & 0.006 & 0.001 & -0.026 & -0.015 & & \\
Constant & $(0.90)$ & $(0.14)$ & $(0.02)$ & $(0.91)$ & $(0.25)$ & & \\
& -0.008 & -0.276 & -0.101 & -0.027 & 0.177 & -0.043 & 0.569 \\
Observations & $(0.09)$ & $(1.41)$ & $(0.85)$ & $(0.24)$ & $(1.04)$ & $(0.31)$ & $(2.65)^{* * *}$ \\
R-squared & 1208 & 293 & 583 & 791 & 311 & 683 & 460 \\
\hline & 0.02 & 0.03 & 0.03 & 0.02 & 0.02 & 0.03 & 0.04 \\
\hline
\end{tabular}




\section{Table 10. Fixed Effects Panel Estimates: Cost of Finance}

The table reports regression estimates with firm-level fixed effects using the panel component of the 2002 and 2005 BEEPS. The dependent variable is: "How problematic is cost of financing (e.g. interest rates and charges) for the operation and growth of your business?" (1=major obstacle, $2=$ moderate obstacle, $3=$ minor obstacle, $4=$ no obstacle). Opaque firms are those that did not have external auditors or international accounting standards in both 2002 and 2005. Transparent firms are those with external auditors or international accounting standards in both 2002 and 2005. Small and large firms are, respectively, firms with less or more than 50 employees in both 2002 and 2005. The groups of High and Low reform countries are defined on the basis of the Enterprise reform index. High reform countries are those where the value of this index is higher then the median value (2.5) in both 2002 and 2005: Croatia, Czech Rep, Estonia, Hungary, Latvia, Lithuania, Poland, Slovak Rep, Slovenia. Low reform countries are those where the value of this index is lower then the median value (2.5) in both 2002 and 2005: Albania, Armenia, Belarus, Bulgaria, Georgia, Kazakhstan, Kyrgyzstan, Macedonia, Moldova, Romania, Russia, Serbia, Ukraine. T-statistics are reported in parentheses. One star indicates that the estimated coefficient is significantly different from zero at $10 \%$ level; two stars at $5 \%$; three stars at $1 \%$.

\begin{tabular}{|c|c|c|c|c|c|c|c|}
\hline & Baseline & Opaque & $\begin{array}{c}\text { Transpa- } \\
\text { rent }\end{array}$ & $\begin{array}{l}\text { Small } \\
\text { firm }\end{array}$ & $\begin{array}{l}\text { Large } \\
\text { firm }\end{array}$ & $\begin{array}{l}\text { Low } \\
\text { reform }\end{array}$ & $\begin{array}{l}\text { High } \\
\text { reform }\end{array}$ \\
\hline Information sharing index & $\begin{array}{c}0.136 \\
(3.07)^{* * *}\end{array}$ & $\begin{array}{c}0.186 \\
(2.08)^{* *}\end{array}$ & $\begin{array}{c}0.170 \\
(2.54)^{* *}\end{array}$ & $\begin{array}{c}0.177 \\
(3.18)^{* * *}\end{array}$ & $\begin{array}{l}0.057 \\
(0.63)\end{array}$ & $\begin{array}{c}0.179 \\
(2.62)^{* * *}\end{array}$ & $\begin{array}{l}0.008 \\
(0.09)\end{array}$ \\
\hline Small firm & $\begin{array}{l}0.167 \\
(1.23)\end{array}$ & $\begin{array}{l}-0.006 \\
(0.01)\end{array}$ & $\begin{array}{l}0.251 \\
(1.54)\end{array}$ & & & $\begin{array}{l}0.115 \\
(0.68)\end{array}$ & $\begin{array}{l}0.211 \\
(0.85)\end{array}$ \\
\hline Transparency & $\begin{array}{l}0.080 \\
(1.54)\end{array}$ & & & $\begin{array}{l}0.043 \\
(0.68)\end{array}$ & $\begin{array}{l}0.154 \\
(1.47)\end{array}$ & $\begin{array}{l}0.088 \\
(1.29)\end{array}$ & $\begin{array}{l}0.095 \\
(1.04)\end{array}$ \\
\hline Per capita GDP & $\begin{array}{l}0.042 \\
(1.58)\end{array}$ & $\begin{array}{l}0.048 \\
(0.89)\end{array}$ & $\begin{array}{l}0.042 \\
(1.14)\end{array}$ & $\begin{array}{c}0.067 \\
(2.08)^{* *}\end{array}$ & $\begin{array}{c}-0.016 \\
(0.30)\end{array}$ & $\begin{array}{l}-0.109 \\
(0.67)\end{array}$ & $\begin{array}{l}-0.076 \\
(1.58)\end{array}$ \\
\hline Inflation & $\begin{array}{c}-0.005 \\
(3.05)^{* * *}\end{array}$ & $\begin{array}{l}-0.005 \\
(1.63)\end{array}$ & $\begin{array}{c}-0.006 \\
(2.21)^{* *}\end{array}$ & $\begin{array}{c}-0.005 \\
(2.37)^{* *}\end{array}$ & $\begin{array}{l}-0.007 \\
(2.09)^{* *}\end{array}$ & $\begin{array}{c}-0.005 \\
(2.73)^{* * *}\end{array}$ & $\begin{array}{l}-0.017 \\
(2.50)^{* *}\end{array}$ \\
\hline Foreign bank assets & $\begin{array}{l}-0.000 \\
(0.13)\end{array}$ & $\begin{array}{l}0.007 \\
(1.00)\end{array}$ & $\begin{array}{c}-0.004 \\
(1.06)\end{array}$ & $\begin{array}{l}-0.003 \\
(0.73)\end{array}$ & $\begin{array}{l}0.003 \\
(0.65)\end{array}$ & $\begin{array}{l}-0.003 \\
(0.46)\end{array}$ & $\begin{array}{l}-0.003 \\
(0.90)\end{array}$ \\
\hline Enterprise reform index & $\begin{array}{l}-0.043 \\
(1.77)^{*}\end{array}$ & $\begin{array}{l}-0.031 \\
(0.76)\end{array}$ & $\begin{array}{l}-0.040 \\
(0.91)\end{array}$ & $\begin{array}{l}-0.040 \\
(1.48)\end{array}$ & $\begin{array}{l}-0.027 \\
(0.44)\end{array}$ & & \\
\hline Constant & $\begin{array}{l}-0.130 \\
(1.52)\end{array}$ & $\begin{array}{l}-0.359 \\
(1.90)^{*}\end{array}$ & $\begin{array}{l}-0.058 \\
(0.51)\end{array}$ & $\begin{array}{l}-0.189 \\
(1.77)^{*}\end{array}$ & $\begin{array}{l}0.048 \\
(0.27)\end{array}$ & $\begin{array}{l}-0.082 \\
(0.62)\end{array}$ & $\begin{array}{c}0.398 \\
(1.91)^{*}\end{array}$ \\
\hline & 1218 & 29 & 59 & 79 & 315 & 669 & 485 \\
\hline $\mathrm{R}$-squared & 0.03 & 0.04 & 0.03 & 0.03 & 0.03 & 0.02 & 0.03 \\
\hline
\end{tabular}




\section{Swiss National Bank Working Papers published since 2004:}

2004-1 Samuel Reynard: Financial Market Participation and the Apparent Instability of Money Demand

2004-2 Urs W. Birchler and Diana Hancock: What Does the Yield on Subordinated Bank Debt Measure?

2005-1 Hasan Bakhshi, Hashmat Khan and Barbara Rudolf: The Phillips curve under state-dependent pricing

2005-2 Andreas M. Fischer: On the Inadequacy of Newswire Reports for Empirical Research on Foreign Exchange Interventions

2006-1 Andreas M. Fischer: Measuring Income Elasticity for Swiss Money Demand: What do the Cantons say about Financial Innovation?

2006-2 Charlotte Christiansen and Angelo Ranaldo: Realized Bond-Stock Correlation: Macroeconomic Announcement Effects

2006-3 Martin Brown and Christian Zehnder: Credit Reporting, Relationship Banking, and Loan Repayment

2006-4 Hansjörg Lehmann and Michael Manz: The Exposure of Swiss Banks to Macroeconomic Shocks - an Empirical Investigation

2006-5 Katrin Assenmacher-Wesche and Stefan Gerlach: Money Growth, Output Gaps and Inflation at Low and High Frequency: Spectral Estimates for Switzerland

2006-6 Marlene Amstad and Andreas M. Fischer: Time-Varying Pass-Through from Import Prices to Consumer Prices: Evidence from an Event Study with Real-Time Data

2006-7 Samuel Reynard: Money and the Great Disinflation

2006-8 Urs W. Birchler and Matteo Facchinetti: Can bank supervisors rely on market data? A critical assessment from a Swiss perspective

2006-9 Petra Gerlach-Kristen: A Two-Pillar Phillips Curve for Switzerland

2006-10 Kevin J. Fox and Mathias Zurlinden: On Understanding Sources of Growth and Output Gaps for Switzerland

2006-11 Angelo Ranaldo: Intraday Market Dynamics Around Public Information Arrivals

2007-1 Andreas M. Fischer, Gulzina Isakova and Ulan Termechikov: Do FX traders in Bishkek have similar perceptions to their London colleagues? Survey evidence of market practitioners' views 
2007-2 Ibrahim Chowdhury and Andreas Schabert: Federal Reserve Policy viewed through a Money Supply Lens

2007-3 Angelo Ranaldo: Segmentation and Time-of-Day Patterns in Foreign Exchange Markets

2007-4 Jürg M. Blum: Why ‘Basel II’ May Need a Leverage Ratio Restriction

2007-5 Samuel Reynard: Maintaining Low Inflation: Money, Interest Rates, and Policy Stance

2007-6 Rina Rosenblatt-Wisch: Loss Aversion in Aggregate Macroeconomic Time Series

2007-7 Martin Brown, Maria Rueda Maurer, Tamara Pak and Nurlanbek Tynaev: Banking Sector Reform and Interest Rates in Transition Economies: Bank-Level Evidence from Kyrgyzstan

2007-8 Hans-Jürg Büttler: An Orthogonal Polynomial Approach to Estimate the Term Structure of Interest Rates

2007-9 Raphael Auer: The Colonial Origins Of Comparative Development: Comment. A Solution to the Settler Mortality Debate

2007-10 Franziska Bignasca and Enzo Rossi: Applying the Hirose-Kamada filter to Swiss data: Output gap and exchange rate pass-through estimates

2007-11 Angelo Ranaldo and Enzo Rossi: The reaction of asset markets to Swiss National Bank communication

2007-12 Lukas Burkhard and Andreas M. Fischer: Communicating Policy Options at the Zero Bound

2007-13 Katrin Assenmacher-Wesche, Stefan Gerlach, and Toshitaka Sekine: Monetary Factors and Inflation in Japan

2007-14 Jean-Marc Natal and Nicolas Stoffels: Globalization, markups and the natural rate of interest

2007-15 Martin Brown, Tullio Jappelli and Marco Pagano: Information Sharing and Credit: Firm-Level Evidence from Transition Countries 
Swiss National Bank Working Papers are also available at www.snb.ch, section Publications/Research Subscriptions or individual issues can be ordered at Swiss National Bank, Fraumünsterstrasse 8, CH-8022 Zurich, fax+41 4463181 14, E-mail library@snb.ch 